Review Article

\title{
Effect of Active Ingredients of Chinese Herbal Medicine on the Rejuvenation of Healthy Aging: Focus on Stem Cells
}

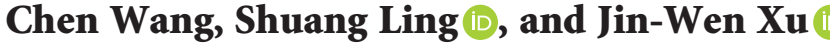 \\ Institute of Interdisciplinary Medical Science, Shanghai University of Traditional Chinese Medicine, Shanghai 201203, China \\ Correspondence should be addressed to Shuang Ling; sarah_ling@126.com and Jin-Wen Xu; jwxu1001@163.com
}

Received 18 March 2020; Revised 3 June 2020; Accepted 19 June 2020; Published 8 July 2020

Academic Editor: Francisco Solano

Copyright ( 2020 Chen Wang et al. This is an open access article distributed under the Creative Commons Attribution License, which permits unrestricted use, distribution, and reproduction in any medium, provided the original work is properly cited.

\begin{abstract}
Stem cells (SCs) are special types of cells with the ability of self-renewal and multidirectional differentiation. As the organism ages, the ability to maintain homeostasis and regeneration deteriorates and the number and activity of stem cells decline. Theoretically, the restoration of stem cells might reverse aging. However, due to their own aging, donor-derived immune rejection, and difficulties in stem cell differentiation control, a series of problems need to be solved to realize the potential for clinical application of stem cells. Chinese herbal medicine is a nature drug library which is suitable for the long-term treatment of aging-related diseases. Modern pharmacological studies have revealed that many active ingredients of Chinese herbal medicines with the effect of promoting stem cells growth and differentiation mainly belong to "reinforcing herbs." In recent years, exploration of natural active ingredients from Chinese herbal medicines for delaying aging, improving the stem cell microenvironment, and promoting the proliferation and differentiation of endogenous stem cells has attracted substantial attention. This article will focus on active ingredients from Chinese herbs-mediated differentiation of stem cells into particular cell type, like neural cells, endothelial cells, cardiomyocytes, and osteoblasts. We will also discuss the effects of these small molecules on Wnt, Sonic Hedgehog, Notch, eNOScGMP, and MAP kinase signal transduction pathways, as well as reveal the role of estrogen receptor $\alpha$ and PPAR $\gamma$ on selectively promoting or inhibiting stem cells differentiation. This review will provide new insights into the health aging strategies of active ingredients in Chinese herbal medicine in regenerative medicine.
\end{abstract}

\section{Introduction}

Stem cells are undifferentiated cells capable of self-renewal to produce unlimited cells of the same type, as well as being able to differentiate into other cell types. During differentiation, stem cells gradually lose their pluripotency and become specialized cells with a more specialized function. Compared with embryonic stem cells, adult stem cells exist in highly differentiated tissues, which dedifferentiate and replace dead and damaged cells under appropriate conditions. Adult stem cells include neural stem cells (NSCs), hematopoietic stem cells (HSCs), bone marrow mesenchymal stem cells (BMSCs), epidermal stem cells (ESCs), and adipose-derived stem cells (ADSCs). The multipotential characteristics of stem cells may provide beneficial strategy for age-related diseases treatment.
With aging, the ability to maintain body homeostasis and regenerate damaged tissues decreases, resulting in the occurrence of age-related diseases. As humans age, metabolism, self-renewal, differentiation, or quiescent state of endogenous stem cells are damaged and become exhausted. The stem cell niche, as the in vivo microenvironment where stem cells reside, changes with age, which limited the tissue regeneration $[1,2]$. Because of the attenuation of adult stem cells regenerative potential in the elderly, the reduced benefits of autologous stem cell therapy and the immune rejection of other donors have become obstacles to stem cell transplantation therapy [3]. If we can provide correct small molecules intervention and proper survival microenvironment for ameliorating the potential of aging stem cell regeneration in tissue repair, it will improve the efficiency of endogenous stem cell-mediated tissue healing mechanism. 
Chinese herbal medicine has a long history of treating aging-related diseases. Modern medical research has revealed that many active ingredients of Chinese herbal medicines with the characteristics of "Tonifying-Qi," "Tonifying-Kidney," and "Tonifying-Blood" have the effect of promoting the growth and differentiation of stem cells. As a complementary approach, the active ingredients of traditional Chinese medicine target specific signal pathways and epigenetic processes, offering a powerful tool for manipulating cell fate to achieve the desired effect.

This envisages that Chinese herbal medicine treatment will become a rejuvenation strategy for healthy aging, which is beneficial to improve the microenvironment of stem cells in vivo. It also promotes the autonomous and intrinsic signaling pathways of proliferation and differentiation, as well as the repair of damaged tissue by endogenous stem cells.

\section{Effect of Chinese Medical Herbs on Stem Cell Differentiation}

The active ingredients of traditional Chinese medicine are mostly small molecular compounds, which are attractive approaches to control the stem cell fate. The biological effects of small molecules are fast and dose-dependent, allowing precise control of specific pathological situations. The small molecules are easier to handle and administrate, which makes them more practical for clinical applications and therapeutic development compared to genetic interventions. Chemical regulation of cell fate provides a wide range of applications in delaying stem cell aging and promoting tissue and organ regeneration. Small molecules of traditional Chinese medicine can target endogenous stem cells and enhance their self-renewal, expansion, differentiation, and viability in regenerative medicine. A summary list of stem cell differentiation induced by active small molecules of Chinese herbal medicine is shown in Table 1.

2.1. Neural Differentiation. Numerous studies have shown that the active ingredients of Chinese medical herbs have the effect of promoting nerve cells differentiation. Ginsenoside Rg1 treatment of mouse embryonic stem cells and human adipose-derived stem cells induced a significant increase in neuron-like cell populations in a time- and dose-dependent manner and upregulated the mRNA or protein expression of neuronal-specific neurofilament (NEFM), neural cell adhesion molecule (NCAM), synapsin-1 (SYN-1), and $\beta$-tubulin III, respectively $[4,5]$. Saponins derived from Panax notoginseng also had neurodifferentiation promoting effects similar to ginsenosides [6, 7]. Salvianolic acid B and tanshinone IIA are active substances from the root of Salvia miltiorrhiza Bunge, which is widely used as a traditional Chinese medical herb for stroke. In vitro, salvianolic acid B improved the differentiation of neurospheres into neuronal lineage and further promoted the outgrowth of neurites and differentiated into neurons [8]. Tanshinone IIA treatment also induced neuronal differentiation in three cell models, immortalized C17.2 neural progenitor cells, rat embryonic cortical NSCs, and rat PC12 pheochromocytoma cells, in a dose-dependent manner $[9,10]$. Baicalin is a flavonoid found in the Chinese herb Scutellaria baicalensis. Previous studies had demonstrated that baicalin could promote the neural differentiation of human iPS cells, immortalized mouse C17.2 neural progenitor cells, and rat embryonic cortical NSCs [11-13]. Interestingly, baicalin improved neural differentiation but inhibited glial formation [12]. Many other traditional Chinese medical herbal ingredients also have the ability to differentiate stem cells into specialized cell subtypes. Recent studies revealed that astragaloside IV, astragalus polysaccharide, and astraisoflavan, three effective active substances of Astragalus propinquus Schischkin, could induce the differentiation of NSCs into dopamine neurons and promote the mRNA expression of dopaminergic neuron-specific tyrosine hydroxylase and dopamine transporter in vitro [14]. Ginkgolide B is a biologically active terpenic lactone present in Ginkgo biloba. Li et al. [15] demonstrated that Ginkgolide B promoted cell cycle withdrawal and neuronal differentiation of adult NSCs in the subventricular zone (SVZ) after birth of the mouse lateral ventricle. Natural lignans and iridoid compounds including aucubin facilitated neuronal differentiation and neurite outgrowth in NSCs from the rat embryonic hippocampus or in rat neuronal hippocampal cell line $\mathrm{HiB} 5$ cells $[16,17]$. Salidroside, a glucoside of tyrosol found in the plant Rhodiola rosea Linn., could induce rat BMSC differentiate into cholinergic nerve cells in vitro. When salidroside stimulated rat BMSCs, the expression levels of neuronspecific enolase (NSE), brain-derived neurotrophic factor (BDNF), $\beta$-tubulin III, and glial fibrillary acidic protein (GFAP) on the 6th day; the positive rates of NSE, microtubule-associated protein-2 (MAP-2), $\beta$-tubulin III, and GFAP in the immunofluorescence staining images on the 3 th day; and the acetylcholine (Ach) positive rate on the $3 \mathrm{rd}$, 6 th, and 9th days were significantly higher than those of the control group [18]. The detailed signaling pathways of active ingredients inducing neural cell differentiation are shown in Figure 1.

\subsection{Endothelial Cell and Cardiomyocyte Differentiation.} Circulating endothelial progenitor cells (EPCs) may contribute to vasculogenesis after ischemia and tissue injury, so studies have been conducted to investigate the function of EPCs in ischemic diseases. Our previous studies have found that bavachalcone, an isopentenyl chalcone from Psoralea corylifolia Linn., promoted the differentiation of EPCs and neovascularization in vivo [19]. In a series of cell-based experiments, Tang and his colleagues observed that ginkgolide B, icariin, tanshinone IIA, astragaloside IV, ginsenoside Rg1, and salidroside exert angiogenic endothelial differentiation effects of human bone marrow-derived EPCs [20-24]. A study reported that salvianolic acid A could augment EPC numbers and promote EPC migration, adhesion, and the vasculogenesis capacity in myocardial ischemia-reperfusion (I/R) rat model [25]. In another study, monotropein, an iridoid monoterpenoid, promoted mobilization and differentiation of bone marrowderived EPCs and attenuated cell autophage and apoptosis, 
TABLE 1: Small molecule compounds from Chinese medical herbs inducing stem cell differentiation.

\begin{tabular}{|c|c|c|c|c|c|}
\hline Active ingredients & Differentiated cells & Stem cells or model & Pathways & Effects & References \\
\hline \multirow[t]{2}{*}{ Astragaloside IV } & $\begin{array}{l}\text { Endothelial cell-like } \\
\text { cells }\end{array}$ & $\begin{array}{l}\text { Rat mesenchymal stem } \\
\text { cells }\end{array}$ & N/A & $\begin{array}{c}\text { 1. Differentiated into } \\
\text { endothelial cell-like cells and } \\
\text { promoted tube formation in } \\
\text { vitro } \\
\text { 2. Upregulated the expression } \\
\text { of Cx37, Cx } 40 \text {, and Cx43 and } \\
\text { enhanced gap junctional } \\
\text { intercellular communication } \\
\text { (GJIC) function }\end{array}$ & {$[22]$} \\
\hline & Neuronal cells & Rat neural stem cells & Sonic hedgehog & $\begin{array}{l}\text { 1. Differentiation into } \\
\text { dopamine neurons } \\
\text { 2. Promoted the expressions of } \\
\text { Shh, Nurr1, and Ptx3 mRNAs }\end{array}$ & {$[14]$} \\
\hline Astraisoflavan & Neuronal cells & Rat neural stem cells & Sonic hedgehog & $\begin{array}{l}\text { 1. Differentiation into } \\
\text { dopamine neurons } \\
\text { 2. Promoted the expressions of } \\
\text { Shh, Nurr1, and Ptx3 mRNAs }\end{array}$ & {$[14]$} \\
\hline Aucubin & Neuronal cells & $\begin{array}{l}\text { Rat neural stem cells and } \\
\text { neural precursor cells }\end{array}$ & N/A & $\begin{array}{l}\text { 1. Promoted lengthening and } \\
\text { thickness of axons and } \\
\text { remyelination at } 3 \text { weeks after } \\
\text { sciatic nerve injury } \\
\text { 2. Promoted differentiation of } \\
\text { neural precursor cells into } \\
\text { GABAergic neurons }\end{array}$ & $\begin{array}{c}{[16,17,} \\
129]\end{array}$ \\
\hline \multirow{3}{*}{ Baicalin } & Cardiomyocytes & $\begin{array}{c}\text { Murine embryonic stem } \\
\text { cells }\end{array}$ & N/A & $\begin{array}{l}\text { 1. Increased the proportion of } \\
a \text {-actinin-positive } \\
\text { cardiomyocytes } \\
\text { 2. Upregulated cardiac specific } \\
\text { genes } a \text {-MHC, MLC-2v, and } \\
\text { ANP }\end{array}$ & {$[36]$} \\
\hline & Neuronal cells & $\begin{array}{l}\text { Neural stem cells derived } \\
\text { from the cortex of } \\
\text { embryonic E15-16 SD } \\
\text { rats }\end{array}$ & N/A & $\begin{array}{l}\text { 1. Increased the percentages of } \\
\text { mature neuronal marker MAP- } \\
\text { 2-positive staining cells and } \\
\text { decreased glial marker GFAP } \\
\text { staining cells } \\
\text { 2. Downregulated the } \\
\text { expression of } p \text {-stat } 3 \text { and Hes } 1 \\
\text { but upregulated the } \\
\text { expressions of NeuroD1 and } \\
\text { Mash1 }\end{array}$ & {$[13]$} \\
\hline & Osteoblasts & N/A & $\begin{array}{l}\text { Wnt } / \beta \text {-catenin } \\
\text { signaling }\end{array}$ & $\begin{array}{l}\text { 1. Increased significantly the } \\
\text { osteoblastic mineralization } \\
\text { levels of mRNAs encoding the } \\
\text { bone differentiation markers } \\
\text { OCN, OPN, and COL-1 }\end{array}$ & {$[54]$} \\
\hline Bavachalcone & Endothelial cells & $\begin{array}{l}\text { Rat bone marrow } \\
\text { mesenchymal stem cells } \\
\text { and rat hindlimb } \\
\text { ischemia model }\end{array}$ & $\begin{array}{l}\text { ROR } \alpha- \\
\text { erythropoietin- } \\
\text { AMPK axis }\end{array}$ & $\begin{array}{l}\text { 1. Promoted rat bone marrow- } \\
\text { derived cells to differentiate } \\
\text { into EPC significantly } \\
\text { 2. Stimulated blood flow } \\
\text { recovery in ischemic } \\
\text { hindlimbs, increased } \\
\text { circulating EPC, and promoted } \\
\text { capillary neovascularization }\end{array}$ & {$[19]$} \\
\hline Berberine & Osteoblasts & $\begin{array}{l}\text { Bone marrow-derived } \\
\text { mesenchymal stem cells }\end{array}$ & $\begin{array}{l}\text { Wnt } / \beta \text {-catenin } \\
\text { signaling }\end{array}$ & $\begin{array}{c}\text { Promoted osteogenic } \\
\text { differentiation and osteogenic } \\
\text { genes Runx2, OPN, and OCN } \\
\text { expression }\end{array}$ & {$[132]$} \\
\hline
\end{tabular}


Table 1: Continued.

\begin{tabular}{|c|c|c|c|c|c|}
\hline Active ingredients & Differentiated cells & Stem cells or model & Pathways & Effects & References \\
\hline Catalpol & Osteoblasts & $\begin{array}{c}\text { Bone marrow } \\
\text { mesenchymal stem cells }\end{array}$ & $\begin{array}{l}\text { Wnt } / \beta \text {-catenin } \\
\text { signaling }\end{array}$ & $\begin{array}{l}\text { 1. Enhances the osteogenic } \\
\text { differentiation } \\
\text { 2. Significantly enhanced } \\
\text { osteoblast-specific gene } \\
\text { expression, alkaline } \\
\text { phosphatase activity, and } \\
\text { calcium deposition }\end{array}$ & {$[53]$} \\
\hline Curcumin & Cardiomyocytes & $\begin{array}{c}\text { Human embryonic stem } \\
\text { cells }\end{array}$ & NO-cGMP signaling & $\begin{array}{l}\text { 1. Promoted differentiation } \\
\text { into cardiomyocytes } \\
\text { 2. Significantly increased the } \\
\text { gene expression and protein } \\
\text { levels of NKX2.5, cTNI, MHCs, } \\
\text { and eNOS }\end{array}$ & {$[96]$} \\
\hline \multirow{3}{*}{ Ginkgolide B } & $\begin{array}{l}\text { Endothelial } \\
\text { progenitor cells }\end{array}$ & Human bone marrow & $\begin{array}{l}\text { Akt/eNOS and p38 } \\
\text { MAPK signaling }\end{array}$ & $\begin{array}{l}\text { 1. Promoted proliferation and } \\
\text { endothelial gene expression, } \\
\text { significantly enhanced VEGF- } \\
\text { induced migration response, } \\
\text { and improved the vascular } \\
\text { network composition of EPCs } \\
\text { 2. Induced phosphorylation of } \\
\text { eNOS, Akt, and p38 }\end{array}$ & {$[20]$} \\
\hline & Neuronal cells & $\begin{array}{c}\text { Neural stem cells derived } \\
\text { from mouse } \\
\text { subventricular zone } \\
\text { (SVZ) }\end{array}$ & $\mathrm{Wnt} / \beta$-catenin & $\begin{array}{l}\text { 1. Promoted neuronal } \\
\text { differentiation } \\
\text { 2. Increased the level of nuclear } \\
\beta \text {-catenin and activated the } \\
\text { Wnt pathway }\end{array}$ & {$[15]$} \\
\hline & Osteoblasts & $\begin{array}{l}\text { Rat bone mesenchymal } \\
\text { stem cells and MC3T3- } \\
\text { E1 cells }\end{array}$ & Wnt signaling & $\begin{array}{l}\text { 1. Promotes osteoblast } \\
\text { differentiation } \\
\text { 2. Reduced OVX-induced bone } \\
\text { loss by enhancing osteoblast } \\
\text { activity }\end{array}$ & {$[51]$} \\
\hline $\begin{array}{l}\text { Ginsenoside } \\
\text { Rb1/RE }\end{array}$ & Cardiomyocytes & $\begin{array}{c}\text { Human embryonic stem } \\
\text { cell }\end{array}$ & N/A & $\begin{array}{l}\text { 1. Enhanced differentiation } \\
\text { into cardiomyocytes } \\
\text { 2. Upregulated Nkx2.5, Tbx5, } \\
\text { MHC, and KCNE1 expression }\end{array}$ & {$[32]$} \\
\hline Ginsenoside Rg1 & Neuronal cells & $\begin{array}{l}\text { Mouse embryonic stem } \\
\text { cells and human adipose- } \\
\text { derived stem cells }\end{array}$ & $\begin{array}{l}\text { Wnt } / \beta \text {-catenin } \\
\text { pathway, MEK- } \\
\text { ERK1/2, and PI3K- } \\
\text { Akt signaling }\end{array}$ & $\begin{array}{l}\text { 1. Promoted cell proliferation } \\
\text { and neural phenotype } \\
\text { differentiation } \\
\text { 2. Upregulated the mRNA or } \\
\text { protein expression of NSE, } \\
\text { MAP-2, NEFM, NCAM, } \\
\text { synapsin-1, and } \beta \text {-tubulin III }\end{array}$ & {$[4,5]$} \\
\hline $\begin{array}{l}\text { Ginsenoside } \\
\text { RH2 (S) }\end{array}$ & Osteoblasts & MC3T3-E1 cells & $\begin{array}{l}\text { PKD/AMPK } \\
\text { signaling }\end{array}$ & $\begin{array}{l}\text { 1. Stimulated osteoblastic } \\
\text { differentiation and } \\
\text { mineralization } \\
\text { 2. Enhanced the expression of } \\
\text { Runx2, ALP, OCN, OPN, Osx, } \\
\text { and ColI }\end{array}$ & {$[103]$} \\
\hline
\end{tabular}


TABle 1: Continued.

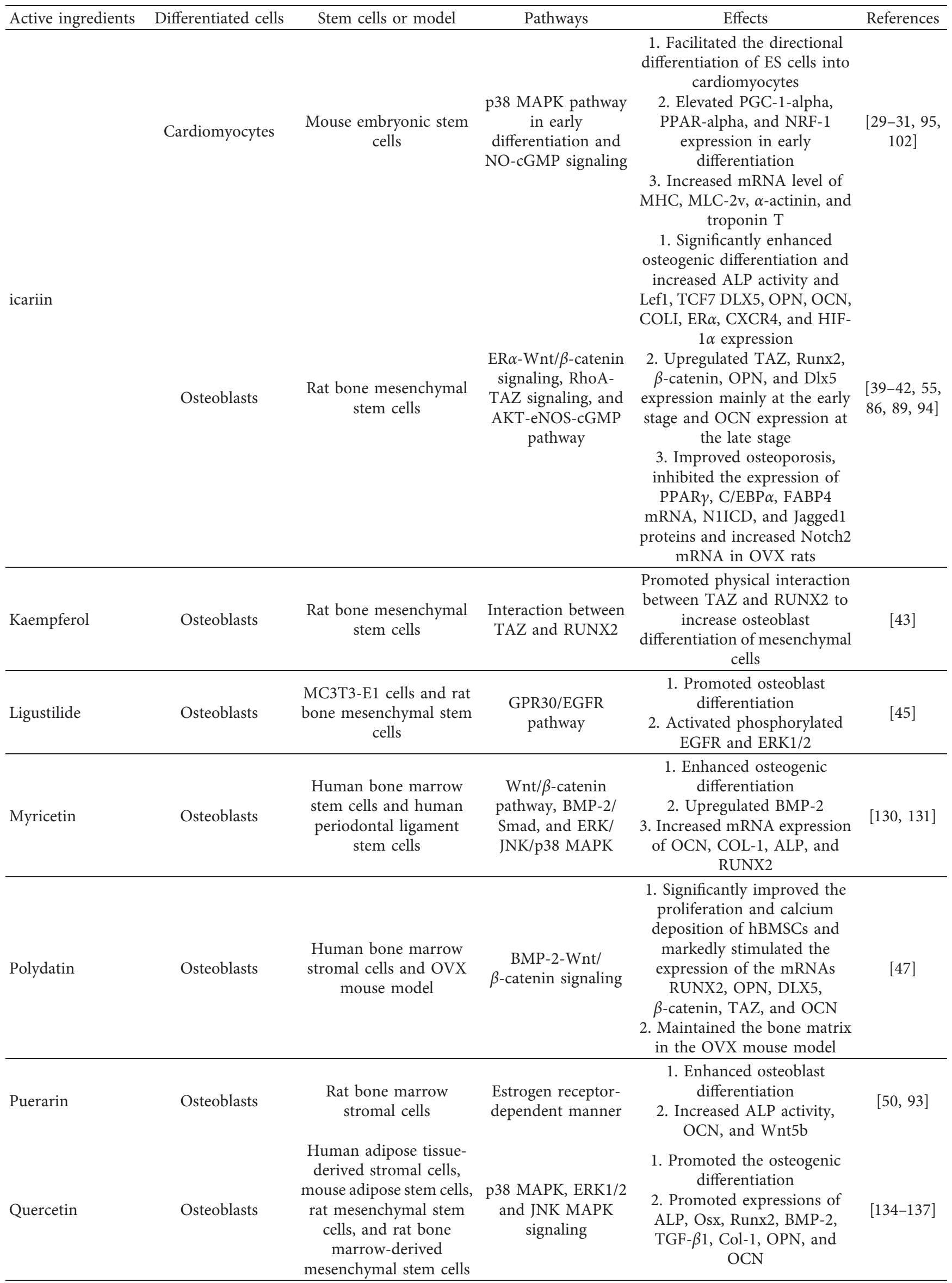


TABle 1: Continued.

\begin{tabular}{|c|c|c|c|c|c|}
\hline Active ingredients & Differentiated cells & Stem cells or model & Pathways & Effects & References \\
\hline \multirow[b]{2}{*}{ Resveratrol } & Neuronal-like cells & $\begin{array}{l}\text { Human bone marrow } \\
\text { mesenchymal stem cells } \\
\text { and human cord blood- } \\
\text { derived mesenchymal } \\
\text { stem cells }\end{array}$ & $\begin{array}{c}\text { Sonic hedgehog } \\
\text { signaling, PKA- } \\
\text { GSK3 } \beta \text {, and } \\
\beta \text {-catenin signaling }\end{array}$ & $\begin{array}{l}\text { 1. Differentiated into neuronal- } \\
\text { like cell types } \\
\text { 2. Significantly increased } \\
\text { expression of the neuronal- } \\
\text { specific marker genes Nestin, } \\
\text { Musashi, CD133, GFAP, NF- } \\
\text { M, MAP-2, and KCNH1 } \\
\text { 3. Increased expressions of } \\
\text { Smo and Glil proteins }\end{array}$ & $\begin{array}{c}{[75,} \\
138-140]\end{array}$ \\
\hline & Osteoblasts & $\begin{array}{l}\text { Mouse embryonic stem } \\
\text { cells, rat adipose-derived } \\
\text { mesenchymal stem cells }\end{array}$ & $\begin{array}{l}\text { AMPK/Ulk1 } \\
\text { pathway, and Sirt-1/ } \\
\text { Runx2 deacetylation }\end{array}$ & $\begin{array}{l}\text { 1. Enhancing osteogenic } \\
\text { differentiation and } \\
\text { mineralization } \\
\text { 2. Enhanced expression of } \\
\text { pluripotency markers Oct3/4, } \\
\text { Sox2, Nanog, Klf4, SSEA-1, } \\
\text { and ALP } \\
\text { 3. Increased expression of } \\
\text { Runx2 and decreased } \\
\text { expression of PPAR- } \gamma\end{array}$ & $\begin{array}{l}{[104,141} \\
142]\end{array}$ \\
\hline Salidroside & Neuronal cells & $\begin{array}{c}\text { Rat bone marrow } \\
\text { mesenchymal stem cells, } \\
\text { mouse mesenchymal } \\
\text { stem cells }\end{array}$ & $\begin{array}{l}\text { Notch and BMP } \\
\text { signaling pathways }\end{array}$ & $\begin{array}{l}\text { 1. Inhibited the proliferation, } \\
\text { increased expression level of } \\
\text { NSE, BDNF, MAP2, } \beta \text {-tubulin } \\
\text { III, GFAP, Wnt3a, } \beta \text {-catenin, } \\
\text { LRP6, and Axin } \\
\text { 2. The positive rate of Ach was } \\
\text { significantly higher on the 3rd, } \\
\text { 6th, and 9th day than on the 1st } \\
\text { day }\end{array}$ & {$[18,56,82]$} \\
\hline \multirow{4}{*}{$\begin{array}{l}\text { Salvianolic acid a/ } \\
\text { B }\end{array}$} & $\begin{array}{l}\text { NF-M }(+) \text { neurons } \\
\text { and NG2 }(+) \\
\text { oligodendrocyte } \\
\text { precursors }\end{array}$ & $\begin{array}{l}\text { Neural stem cells derived } \\
\text { from the cerebral cortex } \\
\text { of embryonic mice, bone } \\
\text { marrow-derived neural } \\
\text { stem cells, and induced } \\
\text { pluripotent stem cells }\end{array}$ & $\begin{array}{l}\mathrm{PI} 3 \mathrm{~K} / \mathrm{AKT} / \mathrm{GSK} 3 \beta / \\
\beta \text {-catenin pathway }\end{array}$ & $\begin{array}{l}\text { 1. Promoted the neurite } \\
\text { outgrowth of neural stem cells } \\
\text { and their differentiation into } \\
\text { neurons } \\
\text { 2. Induced BDNF production }\end{array}$ & $\begin{array}{c}{[8,143,} \\
144]\end{array}$ \\
\hline & Osteoblasts & $\begin{array}{l}\text { Human mesenchymal } \\
\text { stem cells and rat bone } \\
\text { marrow stromal stem } \\
\text { cells }\end{array}$ & $\begin{array}{l}\text { ERK signaling and } \\
\text { NO-cGMP signaling }\end{array}$ & $\begin{array}{c}\text { 1. Significantly promoted } \\
\text { mineralization } \\
\text { 2. Increased ALP activity, } \\
\text { Runx2, osterix, OPG, and OCN } \\
\text { level and the OPG/RANKL } \\
\text { ratio }\end{array}$ & {$[46,97]$} \\
\hline & Hepatocytes & $\begin{array}{c}\text { Human embryonic stem } \\
\text { cells }\end{array}$ & $\begin{array}{c}\text { Through } \\
\text { upregulation of } \\
\text { WNT pathway and } \\
\text { inhibition of Notch } \\
\text { pathway }\end{array}$ & $\begin{array}{c}\text { 1. Promoted hepatocyte } \\
\text { differentiation and increased } \\
\text { expression of albumin, tyrosine } \\
\text { aminotransferase (TAT), } \\
\text { CYP3A4, CYP2C19, UGT1A6, } \\
\text { UGT1A8, and UGT2B7 } \\
\text { 2. Enhanced expression of } \\
\text { TCF3 and LEF1 and } \\
\text { downregulated Jagged2, and } \\
\text { Hes1/5 }\end{array}$ & {$[57]$} \\
\hline & $\begin{array}{l}\text { Alveolar epithelial } \\
\text { cells type I }\end{array}$ & $\begin{array}{l}\text { Rat bone marrow } \\
\text { mesenchymal stem cells }\end{array}$ & WNT pathway & $\begin{array}{l}\text { 1. By day } 14 \text {, the majority of } \\
\text { bone marrow mesenchymal } \\
\text { stem cells were } \\
\text { morphologically differentiated } \\
\text { into alveolar epithelial cells } \\
\text { 2. Significantly increased the } \\
\text { T1 } \alpha \text { and AQP-5 protein levels }\end{array}$ & {$[58]$} \\
\hline
\end{tabular}


TABLE 1: Continued.

\begin{tabular}{|c|c|c|c|c|c|}
\hline Active ingredients & Differentiated cells & Stem cells or model & Pathways & Effects & References \\
\hline Silibinin & Osteoblasts & $\begin{array}{l}\text { Human bone marrow } \\
\text { stem cells }\end{array}$ & $\begin{array}{l}\text { Activating BMP and } \\
\text { RUNX2 pathways }\end{array}$ & $\begin{array}{l}\text { 1. Promoted ALP activity and } \\
\text { mineralization in hBMSCs } \\
\text { 2. Increased the mRNA } \\
\text { expressions of COLI, ALP, } \\
\text { OCN, osterix, BMP-2, and } \\
\text { RUNX2 }\end{array}$ & [133] \\
\hline \multirow[b]{2}{*}{ Tanshinone IIA } & Neuronal-like cells & $\begin{array}{l}\text { Rat bone marrow } \\
\text { mesenchymal stem cells }\end{array}$ & N/A & $\begin{array}{l}\text { Significantly upregulated the } \\
\text { expression levels of Nestin, } \\
\text { NeuN, and NF200 in the } \\
\text { transplanted cells in the } \\
\text { BMSCs + tanshinone IIA } \\
\text { treatment rats compared } \\
\text { among the groups }\end{array}$ & {$[10]$} \\
\hline & Osteoblasts & $\begin{array}{l}\text { Mouse bone marrow } \\
\text { mesenchymal stem cells } \\
\text { and human periodontal } \\
\text { ligament stem cells }\end{array}$ & $\begin{array}{l}\text { ERK1/2-dependent } \\
\text { Runx2 induction and } \\
\text { BMP-Wnt signaling }\end{array}$ & $\begin{array}{l}\text { 1. Enhanced ALP activity on } \\
\text { day } 7 \text { and calcium content on } \\
\text { day } 24 \text { in the process of TSA- } \\
\text { induced osteogenesis of mouse } \\
\text { bone marrow mesenchymal } \\
\text { stem cells } \\
\text { 2. Promoted both osteogenic } \\
\text { differentiation and maturation } \\
\text { of periodontal ligament stem } \\
\text { cells }\end{array}$ & $\begin{array}{c}{[48,70} \\
100]\end{array}$ \\
\hline $\begin{array}{l}2,3,5,4 \text { '- } \\
\text { Tetrahydroxy- } \\
\text { stilbene-2-O- } \beta \text {-D- } \\
\text { glucoside (THSG) }\end{array}$ & Osteoblasts & $\begin{array}{l}\text { Rat mesenchymal stem } \\
\text { cells }\end{array}$ & N/A & $\begin{array}{c}\text { Promoted osteogenic } \\
\text { differentiation and increased } \\
\text { ALP activity and OCN } \\
\text { expression }\end{array}$ & {$[52]$} \\
\hline
\end{tabular}

finally, improving wound healing [26]. Polysaccharide, also called glycan, presents protective effects on cell damage. Astragalus polysaccharide and Morinda officinalis oligosaccharide have been shown to stimulate the proliferation and differentiation of EPCs by releasing growth factors through the paracrine pathway $[27,28]$. The detailed signaling pathways of active ingredients inducing endothelial cell differentiation are shown in Figure 2.

Cardiomyocytes are the chief cell type in the heart. Embryonic stem cells (ESCs) remain a potential source for cardiomyocyte replacement. Several studies from the Lou team indicated that icariin has a role in promoting the differentiation of mouse embryonic stem cells into cardiomyocytes with heartbeat function [29-31]. Ginsenoside Rb1 (panaxadiol) and ginsenoside Re (panaxatriol) treatment upregulated the expression of mesodermal and cardiac transcription factor genes in the early stage of differentiation induction and cardiac sarcomeric genes in the late stage of differentiation maturation [32]. The ginsenoside Rb1 and Re also elevated the expression of potassium voltage-gated channel subfamily E member 1 (KCNE1). Ginsenoside Re treatment showed a longer beating duration compared to the control [32]. Salvianolic acid B alone had little effect, but costimulation with vitamin $\mathrm{C}$ or transforming growth factor beta 1 (TGF- $\beta 1$ ) in a concentration-dependent manner promoted differentiation of embryonic or BMSCs and increased expression of cardiomyocyte maturation markers $[33,34]$. Similarly, salvianolic acid B, protocatechualdehyde, and tanshinone IIA induced human placenta-derived mesenchymal stem cells to differentiate into cardiomyocytes and increased the expression of GATA4, atrial natriuretic peptide (ANP), $\alpha$-actin, and troponin I to differing degrees [35]. In addition, continuous baicalin treatment promoted the differentiation of embryonic stem cells and increased the proportion of $\alpha$-actinin-positive cardiomyocytes and transcript level of cardiac specific markers, such as $\alpha$-myosin heavy chain $(\alpha-\mathrm{MHC})$, ventricular myosin light chain-2 isoform (MLC-2v), and atrial natriuretic peptide (ANP) [36]. Furthermore, puerarin, another flavonoid compound, significantly increased the number of mouse embryonic stem cell-derived cardiomyocytes, induced embryonic stem cells to differentiate into ventricular-like cells elevated typical cardiac marker expression, and presented complete electrophysiological signals [37]. An in vivo study also showed that simultaneous administration of stem cell transplantation with 2,3,5,4'-tetrahydroxystilbene-2-O- $\beta$-dglucoside (THSG) significantly reduced S-T segment elevation, increased heart rate compared with the myocardial infarction group, and upregulated expression of $\mathrm{Nkx} 2.5$, GATA-4, and connexin 43 in myocardial tissue [38]. The detailed signaling pathways of active ingredients inducing cardiomyocyte differentiation are shown in Figure 3.

2.3. Osteoblast Differentiation. Osteoblasts are bone forming cells. Stimulation of osteoblast differentiation from MSCs is an effective therapeutic strategy for bone repair. Several studies indicated that icariin, a flavonoid glycoside of 


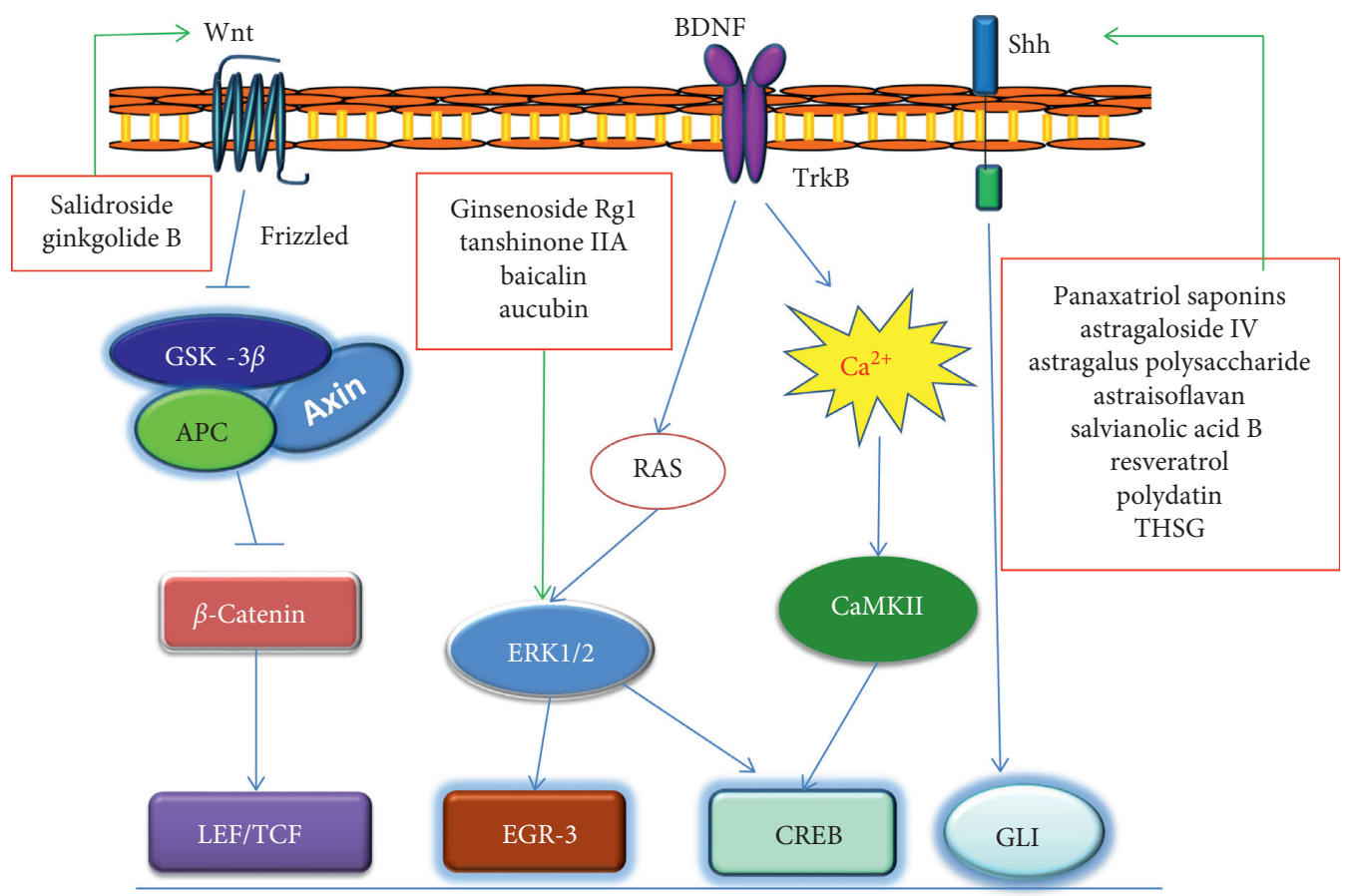

FIGURE 1: Schematic diagram of signaling in neural cell differentiation induced by active ingredients of traditional Chinese medicine. BDNF: brain-derived neurotrophic factor; Shh: sonic hedgehog.

Epimedium brevicornu Maxim., significantly promoted osteogenic differentiation by increasing ALP activity and Runx2, $\beta$-catenin, type I collagen (COLI), osteocalcin $(\mathrm{OCN})$, and osteopontin (OPN) expression in rat BMSCs $[39,40]$. Moreover, icariin had a bidirectional regulation effect on promoting the differentiation of bone marrow mesenchymal stem cells or bone marrow stromal cells into osteoblasts and inhibiting the differentiation into adipocytes $[41,42]$. Micro-CT analysis showed that icariin relieved the loss of cancellous bone of the distal femur in OVX mice [41]. Kaempferol, the main active component of Rhizoma Drynariae, also showed the effect of stimulating osteogenic differentiation $[43,44]$. Interestingly, according to Chinese medicine theories, Epimedium brevicornu Maxim and Rhizoma Drynariae both belong to kidney-tonifying herbs that act to strengthen bones. Ligustilide, an ingredient from Angelica sinensis, had the function in promoting osteoblast differentiation of preosteogenic cell line MC3T3-E1 and BMSCs and inducing the phosphorylation and activity of EGFR and ERK1/2, through the fast response pathway mediated by the estrogen membrane receptor GPR30 [45]. Accumulating results showed that a large number of Chinese herbal ingredients significantly promoted BMSC differentiation, such as salvianolic acid B at $5 \mu \mathrm{M}$, tanshinone IIA at 1 and $5 \mu \mathrm{M}$, polydatin at $30 \mu \mathrm{M}$, salidroside at $0.5-10 \mu \mathrm{M}$, puerarin at $10 \mu \mathrm{M}$, ginkgolide B at $\mu \mathrm{M}$, THSG at $6.25-25 \mu \mathrm{g} /$ $\mathrm{ml}$, catalpol at $50 \mu \mathrm{M}$, and baicalin at $50 \mu \mathrm{M}$ [46-54], among which salvianolic acid B and polydatin can increase the ALP activity and upregulate the expression of osteogenic genes
COLI, OPN, OCN, Runx2, osterix, and DLX5 in human BMSCs $[46,47]$. The detailed signaling pathways of active ingredients inducing osteoblast differentiation are shown in Figure 4.

\section{Signaling Pathways in Stem Cell Differentiation Activated by Chinese Medicinal Herbal Ingredients}

Stem cell differentiation is usually controlled by cell signaling. Here, we discuss the signaling involved in stem cell differentiation activated by Chinese herbal small molecules. Targeted signaling pathways for active small molecules are also shown in Figures 1-4.

3.1. Wnt/ $\beta$-Catenin Signaling. Wnt signaling pathway regulates stem cell differentiation and proliferation. $\beta$-Catenin transcriptional activity is dependent on Wnt signaling, which can be regulated by a variety of Chinese herbal ingredients. For example, icariin activated the $\mathrm{Wnt} / \beta$-catenin signaling pathway during the differentiation of osteoblasts $[41,55]$, and the same pathway was provoked by ginkgolide $\mathrm{B}$ and salidroside during neuronal differentiation $[15,56]$. In addition, in the process of promoting osteoblast differentiation, tanshinone IIA, polydatin, and catalpol also selectively activated the bone morphogenetic proteins (BMP)/ Wnt signaling pathway $[47,48,53]$. Surprisingly, salvianolic acid B promoted bone marrow-derived mesenchymal stem 


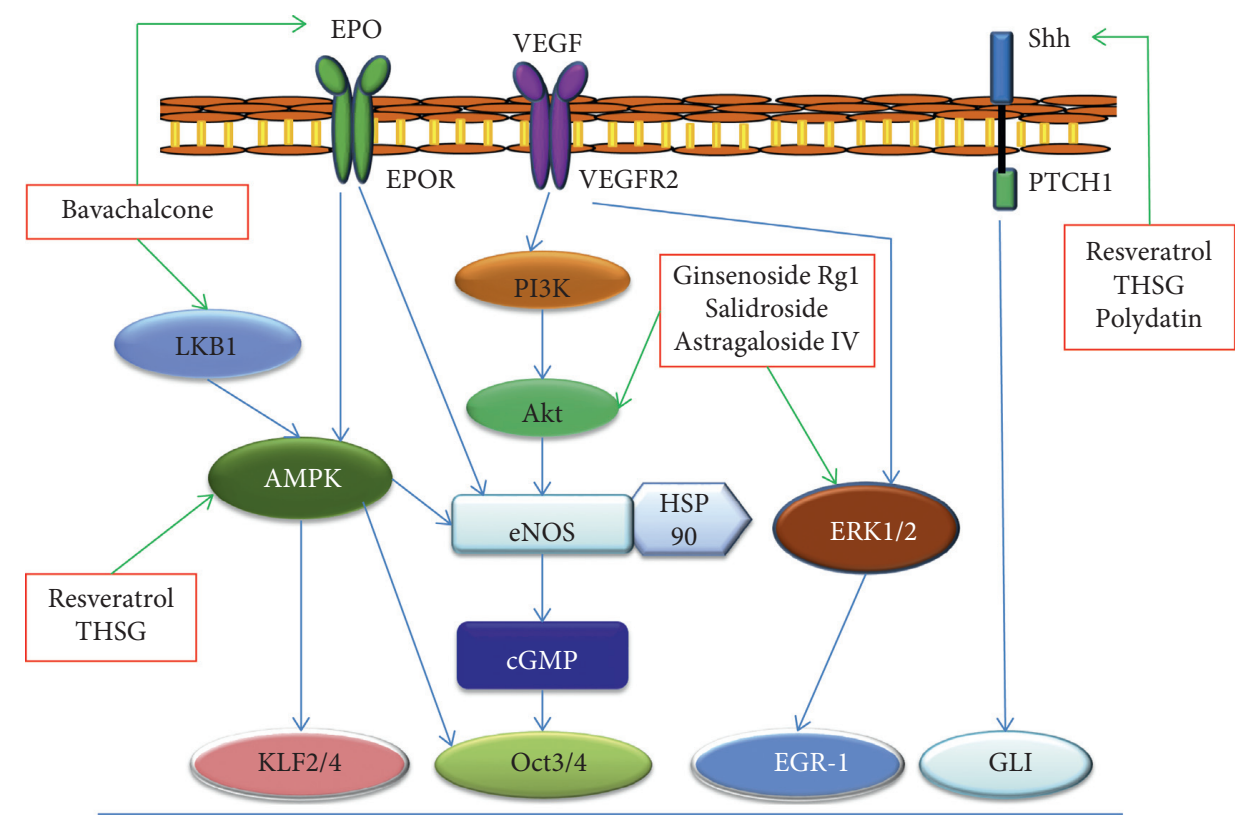

FIgURE 2: Schematic diagram of signaling in endothelial cell differentiation induced by active ingredients of traditional Chinese medicine. EPO: erythropoietin; VEGF: vascular endothelial growth factor; Shh: sonic hedgehog.

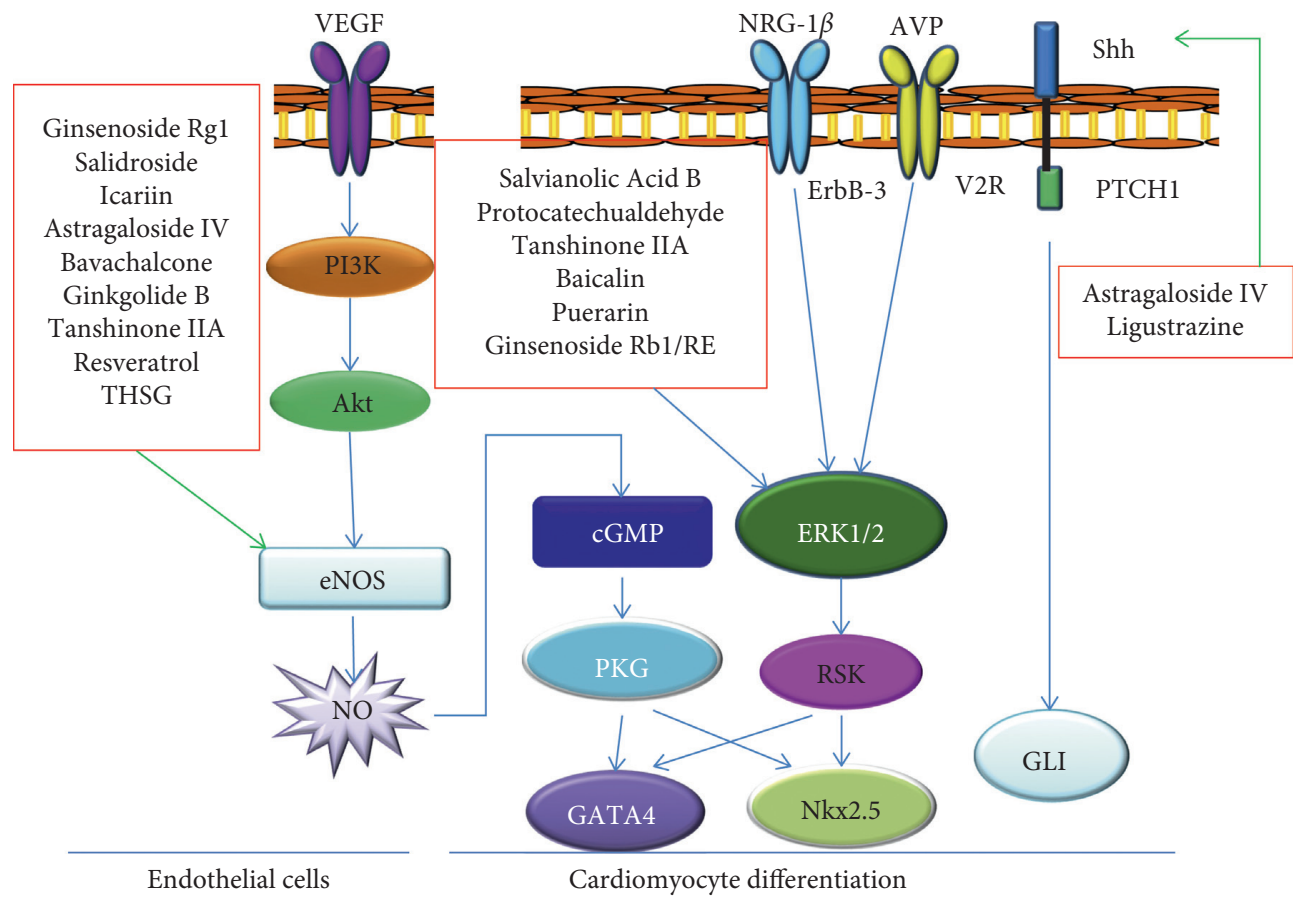

FIGURE 3: Schematic diagram of signaling in cardiomyocyte differentiation induced by active ingredients of traditional Chinese medicine. VEGF: vascular endothelial growth factor; NRG-1 $\beta$ : neuregulin-1 $\beta$; AVP: arginine vasopressin; Shh: sonic hedgehog.

cells to differentiate into alveolar endothelial cell type I and hepatocytes in the same Wnt pathway $[57,58]$.

3.2. Shh/Gli1 Signaling. Sonic hedgehog (Shh) signaling is involved in many types of stem cell differentiation. A large number of studies have revealed that whether stem cells develop into cardiomyocytes $[59,60]$ and vascular endothelial cells [61-63] or differentiate into neurons [64-66] and osteoblasts $[67,68]$, the Shh signaling pathway plays an important role. Astragaloside IV promoted mesenchymal stem cells into neuronal cells [69], endothelial cells [22], and cardiomyocytes [70]. The angiogenesis and cardiomyocyte survival induced by astragaloside IV in rats with acute 
myocardial infarction attributed to upregulation of the gene expression of Shh pathway and their activity of receptors and signal transducers [71]. Astragaloside IV also promoted the proliferation and migration of osteoblast-like cells through the Shh pathway [72]. Gao et al. reported [14] that astragaloside IV, astragalus polysaccharide, and astraisoflavan all promoted the proliferation and committed differentiation of neural stem cells into dopamine neurons. The mechanism of these active ingredients of radix astragali included the Shh signaling pathway. Panaxatriol saponins not only improved the neurological function and reduced infarct volume in middle cerebral artery occlusion (MCAO) rats but also enhanced cerebral perfusion, capillary density, and angiogenesis in ischemic border areas after MCAO surgery and upregulated VEGF and Ang-1 expression by activating the Shh signaling pathway [73]. A study of salvianolic acid injection revealed that salvianolic acid has the effect of improving stroke via Shh signaling [74]. The role of the Shh pathway involved in improving brain function, increasing neural progenitor cell (NPC) proliferation, and promoting the long-term survival of new neurons in the subventricular zone (SVZ) was determined by intraperitoneal injection of salvianolic acid injections for 14 days after 24 hours of stroke onset. Upregulation of nuclear translocations of Shh, Ptch, and Gli1 was observed in the area around the infarction, accompanied by the massive production of brain-derived neurotrophic factor (BDNF) and nerve growth factor (NGF) [74]. Multiple studies have reported that resveratrol protected nerve damage in ischemic stroke by activating the Shh/Gli1 signaling pathway [75]. Interestingly, polydatin, a resveratrol glycoside, also showed the same effect and mechanism [76]. Furthermore, the preparation of Polygonum multiflorum, mainly containing 2,3,5,4'-tetrahydroxystilbene-2-O- $\beta$-D-glucoside (THSG, another resveratrol glycoside), promoted hair growth by stimulation of Shh expression [77]. Chinese wolfberry is used as a dual-use fruit for herbal medicine and food. Its polysaccharide, Lycium bararum polysaccharides, has been reported to improve the differentiation of hippocampal NSCs [78]. Lycium bararum polysaccharides also play a role in reducing apoptosis and oxidative stress by regulating glycogen synthase kinase- $3 \beta$ (GSK-3 $\beta$ ) phosphorylation, Shh, and phosphoinositide 3kinase (PI3K)/Akt signaling pathways [79]. A report indicated that atractylenolide III has the effect on inducing differentiation of mesenchymal stem cells into chondrocytes, enhancing the expression of cartilage-associated proteoglycans, transcription factor Sox9, and chondrogenic markers, as well as significantly increasing expression of Shh signal and its target gene Gli1 [80]. To sum up with western medical concepts, these active ingredients, which come from "Invigorating-Qi" herbs and "Invigorating-blood" herbs according to traditional Chinese medicine theory, can achieve the effect of regulating immunity and bone marrow function through the induction of Shh signal pathway.

3.3. Notch/Jagged Signaling. In addition to activating Wnt signaling, salvianolic acid B also inhibited Notch receptor Notch1/3, Notch ligand Jagged2, and Notch receptor target
Hes1/5 expression in promoting the differentiation of human embryonic stem cells into hepatocytes [57]. Another study showed that serum containing matrine inhibited the proliferation of rat hepatocyte progenitor cell WB-F344 and the expression of Jagg1 and HES1 protein in a concentration- and time-dependent manner, indicating that matrineinduced differentiation of WB-F344 cells through the Notch cell signaling pathway [81]. Salidroside inhibited the proliferation of D1 cells, induced the phenotype of neurons, and upregulated the expression of neuron-specific markers, such as eno2/NSE, microtubule-associated protein-2, and tubb3/ $\beta$-tubulin III, which were related to downregulation of the expression of Notch1 and its downstream target protein Hes1 [82]. Astragaloside IV is known to have neuroprotective property. A study found that in vitro, astragaloside IV induced neural stem cells to differentiate into neuronal marker $\beta$-tubulin III (+) cells and astrocyte marker GFAP ( + ) cells. Astragaloside IV treatment resulted in an increase in the number of $\beta$-tubulin III $(+)$ cells in the hippocampus of rat Alzheimer's disease models transplanted with neural stem cells and improvements in learning and memory [83]. In addition, osthole, a natural coumarin derivative from Cnidium monnieri (L.) Cuss, also increased the number of neurons in hippocampal DG and CA3 regions, significantly improved the learning and memory function of mice with mechanical brain injury, and upregulated the expression of self-renewal genes Notch1 and Hes1 [84]. As a phytoestrogen, icariin increased the expression and activity of estrogen receptor $1(\operatorname{ER} \alpha)$, and this effect of icariin on the differentiation of BMSCs into osteoblasts was blocked by the estrogen nuclear receptor antagonist ICI 182780 [39, 41, 55, 85]. Icariin facilitated osteogenesis in ovariectomized rats by inhibiting peroxisome proliferator-activated receptor $\gamma(\operatorname{PPAR} \gamma)$, CCAAT/ enhancer-binding protein $\alpha(\mathrm{C} / \mathrm{EBP} \alpha)$, and fatty acid binding proteins 4 (FABP4) mRNA expression, and downregulating Jagged 1 protein expression in bone tissue [86]. In addition, transcriptional coactivator TAZ modulated both osteoblast and adipocyte differentiation from mesenchymal stem cells by stimulating the activities of RUNX2 [87] and suppressing the activities of peroxisome proliferator-activated receptor-gamma (PPAR $\gamma)$ [88]. Studies demonstrated that icariin stimulated the activation of TAZ as evidenced by increased total TAZ protein and nuclear translocation in the osteogenic differentiation $[40,89]$. Similar to icariin, kaempferol fortified the activity of TAZ by enhancing RUNX2-mediated osteoblast differentiation and suppressing $\operatorname{PPAR} \gamma$-stimulated adipocyte differentiation [43]. More studies have confirmed that two coumarins isopsoralen and psoralen, four flavonoids isobavachalcone, bavachin, corylifol A, and neobavaisoflavone, and one meroterpene phenol bakuchiol of Psoralea corylifolia [90], glycinol of Glycyrrhiza uralensis [91], notoginsenoside R1 of Panax notoginseng (Burk.) [92], and puerarin of Puerariae Lobatae Radix [93] had the activity of phytoestrogens, which activated estrogen receptor signaling and promoted the differentiation of bone marrow mesenchymal stem cells or mouse embryonic osteogenic precursor cells into osteoblasts. 


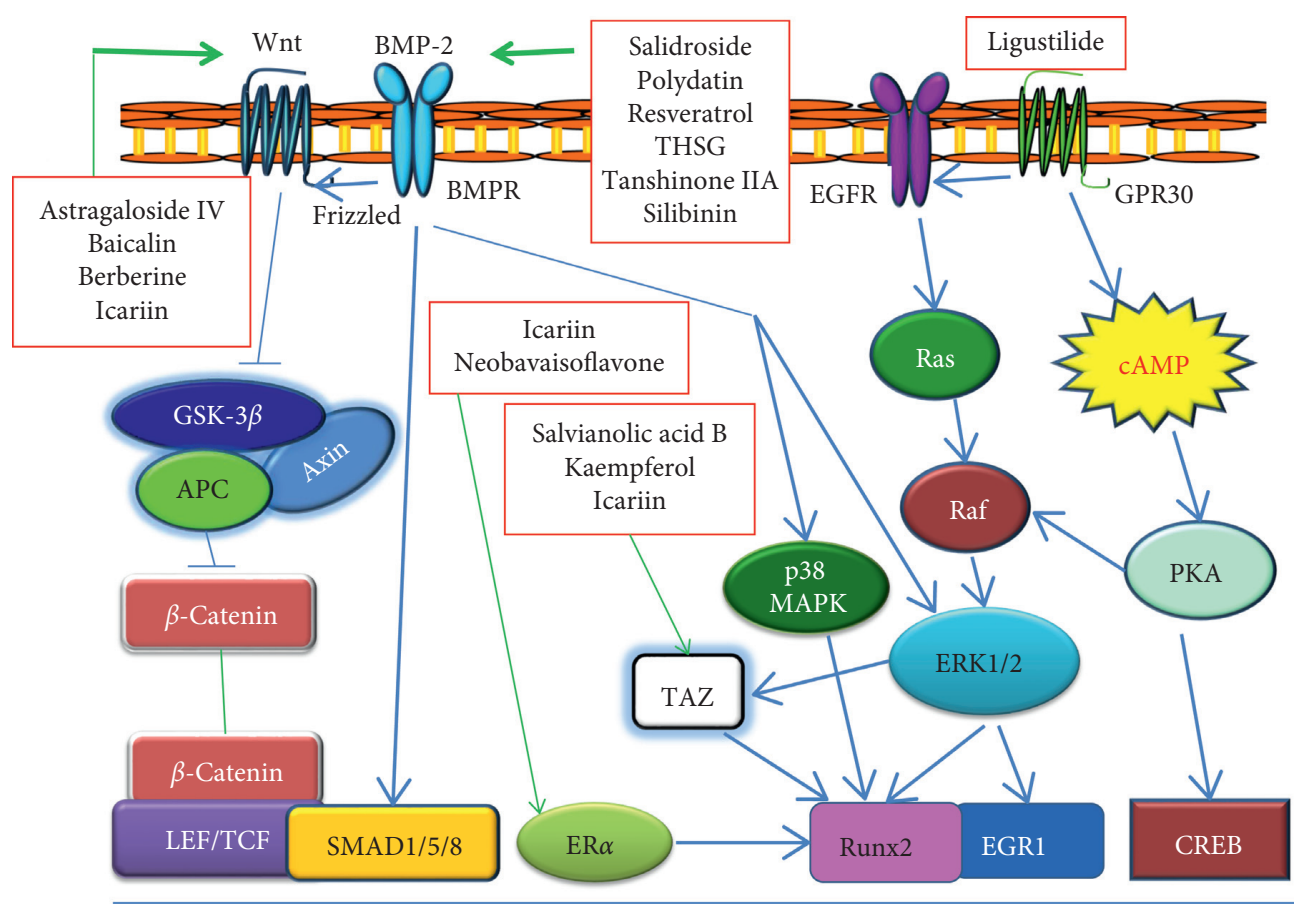

Osteoblast differentiation

FIGURE 4: Schematic diagram of signaling in osteoblast differentiation induced by active ingredients of traditional Chinese medicine. BMP2: bone morphogenetic protein- 2 .

The eNOS/NO/cGMP pathway plays an important role in the differentiation of osteoblasts, cardiomyocytes, and EPCs. In induced osteogenic differentiation, icariin stimulated Akt phosphorylation, enhanced nitric oxide synthase 3 (eNOS) and protein kinase G (PKG) expression, increased nitric oxide (NO) production, and elevated soluble guanylyl cyclase (sGC) and cyclic guanosine monophosphate (cGMP) levels [94]. Icariin also promoted the expression of genes involved in cardiac development and enhanced the increase in endogenous NO production in stem cells [95]. Curcumin, in the same manner of icariin, significantly promoted the differentiation process of embryonic stem cells and increased the gene expression and protein levels of cardiac specific transcription factors NKX2.5, cardiac troponin I, myosin heavy chain, and eNOS. Incubation of cells with curcumin resulted in a dose-dependent increase in intracellular nitrite and elevated levels of intracellular cGMP [96]. Additionally, salvianolic acid B also showed similar effects in inducing nitric oxide production during osteogenic differentiation [97]. Treatment with ginkgolide B and salidroside resulted in cell proliferation, angiogenesis, and differentiation of BMSCs-EPCs; enhanced the ability of EPCs to integrate into vascular networks; and activated Akt phosphorylation and NO production [21, 25]. Studies have reported that osteogenic differentiation of BMSCs is closely related to the activation of the mitogen-activated protein (MAP) kinase signaling pathway and the upregulation of transcription factors Runx2 and Dlx5. Various Chinese herbal ingredients rely on the MAP kinase signaling system in regulating stem cell differentiation, such as icariin [39, 98], salidroside [99], salvianolic acid B [46], and tanshinone IIA [100]. The activity of p38 MAP kinase can control stem cell differentiation switch between neurogenesis and cardiomyogenesis [101], which is one of the mechanisms of icariin in inducing cardiomyocyte differentiation [102].

Furthermore, AMP-activated protein kinase (AMPK) signaling pathway is also involved in bavachalcone-induced differentiation of EPCs and ginsenoside RH 2 (s)-stimulated differentiation of osteoblasts [19,103]. Resveratrol enhanced the expression of pluripotency of mouse embryonic stem cells and increased the pluripotency markers Oct3/4, Sox2, Nanog, and Klf4 by activating the AMPK/Ulk1 pathway [104]. Likewise, THSG, a glycoside of resveratrol, enhanced self-renewal of human dental pulp stem cells via an AMPK signaling pathway [105]. Evidences showed that medicarpin and cryptotanshinone promoted the differentiation of C3H10T1/2 mesenchymal stem cells into brown adipocytes by increasing the expression of thermogenesis marker uncoupling protein 1 (UCP1), upregulating brown fatspecific markers, and reducing the expression of white fat markers, which were associated with the activation of AMPK pathway $[106,107]$.

\section{Roles of Wnt, Shh, and Notch Signaling Pathways in Stem Cell Senescence and Effects of Active Ingredients from Traditional Chinese Medicine}

The antiaging effects of ER $\alpha$, eNOS/NO/cGMP, and AMPK pathways have been reported in a large number of highquality reviews, so it will not be detailed here. In this article, 
we compare the effect of active ingredients of traditional Chinese medicine on Wnt, Shh, and Notch signaling pathways in stem cell differentiation and cell senescence. Wnt, Shh, and Notch signaling not only regulate stem cell differentiation but also participate in cell senescence. Multiple reports suggested that persistent chronic stimulation and dysfunction of Wnt signaling increased cell senescence, mitochondrial biogenesis, and reactive oxygen species (ROS) production [108-111]. Recent study reported that $\mathrm{LiCl}$ activated the $\mathrm{Wnt} / \beta$-catenin pathway and promoted the senescence of mouse neural stem cells; ginsenoside $\operatorname{Rg} 1$ inhibited the activation of the Wnt/ $\beta$-catenin pathway and promoted the proliferation of neural stem cells and hematopoietic stem/progenitor cells $[112,113]$. In another aging mouse model induced by d-galactose, ginsenoside Rg1 prevented oxidative stress, and glutathione peroxidase (GSH-px) and malondialdehyde (MDA) inhibited phospho-histone H2A.X, 8-OHdG, p16 (Ink4a), $\mathrm{Rb}, \mathrm{p} 21$ (Cip1/Waf1), and p53 in senescent Sca- $1^{+}$hematopoietic stem/progenitor cells [113]. However, Shh acting as an endogenous antiaging factor suppresses endometrial stem cell aging [114]. Shh gene delivery also inhibited radiation-induced cell senescence in the salivary glands of mice [115].

Some researchers found that compared with young mice ( 5 weeks old), the expression of Shh decreased in osteoblasts but increased in osteoclasts in old mice (60 weeks old), which is closely related to senile fracture healing [116], due to colocalization of Shh and Glil with osteogenic markers Runx2 and Osx, both of which can be observed during fracture healing [117]. Accumulated evidence indicated that resveratrol and two of its glycosides, polydatin and THSG, could activate the Shh pathway [75-77] and delay cell senescence [118-122]. During endothelial cell senescence, Notch expression was enhanced and activated [123, 124], and Notch signaling further mediated secondary senescence and inflammation in oncogene-induced senescence $[125,126]$. Salidroside was one of the active ingredients of traditional Chinese medicine that not only blocked Notch signaling [82] but also inhibited the replicative cell senescence $[127,128]$.

\section{Conclusion}

Throughout the effect of active ingredients from Chinese herbal medicine on stem cells, the following points can be summarized: (1) the botanical source of these active ingredients is Chinese herbal medicines with the characteristics of "Tonifying-Qi," "Tonifying-Kidney," and "Tonifying-Blood," which are often used to treat aging-related diseases; (2) the same active ingredient induces stem cells to differentiate into different tissue cells; although the active ingredients are different, the signal pathways through which they act are similar; (3) the same active ingredient may require different auxiliary conditions in the differentiation of different tissue cells; for example, salvianolic acid B stimulates differentiation into cardiomyocytes that requires vitamin $\mathrm{C}$ or TGF $\beta$, which is not necessary to differentiate into osteoblasts; (4) several studies have confirmed that there are crosstalk and integration among Wnt, Shh, Notch, and other signaling pathways in regulating stem cell differentiation; for example, salvianolic acid B activated Wnt signaling but prevented Notch signaling when promoting the differentiation of embryonic stem cells into hepatocytes [57]; salvianolic acid B also activated the Shh signaling pathway and promoted functional recovery and neurogenesis in neuroprotection [74]; during the promotion of osteoblast differentiation, the function of salvianolic acid B was also involved in nitric oxide-cGMP pathway [97]; (5) Wnt, Shh, and Notch are not only signal pathways of stem cell differentiation but also important factors of cell senescence. As shown in Table 1 and Figures 1-4, the targeted cells and activated pathways of active ingredients of Chinese herbal medicine are summarized. Nevertheless, more research is necessary to explain the targeted molecules of these active ingredients of Chinese herbal medicine.

\section{Abbreviations}

8-OHdG: 8-Hydroxy-2'-deoxyguanosine

$\alpha$-MHC: $\quad \alpha$-Myosin heavy chain

Ach: Acetylcholine

ADSCs: Adipose-derived stem cells

Akt: $\quad$ Protein kinase B

ALP: $\quad$ Alkaline phosphatase

AMPK: AMP-activated protein kinase

ANP: $\quad$ Atrial natriuretic peptide

BDNF: Brain-derived neurotrophic factor

BMP: $\quad$ Bone morphogenetic proteins

BMSCs: Bone marrow mesenchymal stem cells

BrdU: Bromodeoxyuridine

cGMP: Cyclic guanosine monophosphate

EGFR: Epidermal growth factor receptor

eNOS: $\quad$ Nitric oxide synthase 3

EPCs: Endothelial progenitor cells

$\mathrm{ER} \alpha$ : $\quad$ Estrogen receptor 1

ERK1/2: Extracellular signal-regulated kinase 1/2

ESCs: Embryonic stem cells

FABP4: $\quad$ Fatty acid binding proteins 4

FGF: $\quad$ Fibroblast growth factor

GFAP: Glial fibrillary acidic protein

GPR30: A G protein-coupled receptor for estrogen

GSH-px: Glutathione peroxidase

GSK-3 $\beta$ : Glycogen synthase kinase- $3 \beta$

HSCs: Hematopoietic stem cells

KCNE1: Potassium voltage-gated channel subfamily E member 1

MAP-2: Microtubule-associated protein-2

MAP Mitogen-activated protein kinase

kinase:

MCAO: Middle cerebral artery occlusion

MDA: $\quad$ Malondialdehyde

MLC-2v: Ventricular myosin light chain-2 isoform

NCAM: Neural cell adhesion molecule

NEFM: Neuronal-specific neurofilament

NGF: $\quad$ Nerve growth factor

NO: $\quad$ Nitric oxide

NPCs: Neural progenitor cells 


$\begin{array}{ll}\text { NSCs: } & \text { Neural stem cells } \\ \text { NSE: } & \text { Neuron-specific enolase } \\ \text { OCN: } & \text { Osteocalcin } \\ \text { OPN: } & \text { Osteopontin } \\ \text { OVX: } & \text { Ovariectomized } \\ \text { PI3K: } & \text { Phosphoinositide 3-kinase } \\ \text { PKG: } & \text { Protein kinase G } \\ \text { PPAR } \gamma: & \text { Peroxisome proliferator-activated receptor- } \\ & \text { gamma } \\ \text { SGC: } & \text { Soluble guanylyl cyclase } \\ \text { Shh: } & \text { Sonic hedgehog } \\ \text { SYN-1: } & \text { Synapsin-1 } \\ \text { SVZ: } & \text { Subventricular zone } \\ \text { TAZ: } & \text { Transcriptional coactivator with PDZ-binding } \\ & \text { motif } \\ \text { TGF- } \beta 1: & \text { Transforming growth factor beta 1 } \\ \text { THSG: } & 2,3,5,4 \text { '-Tetrahydroxystilbene-2-O- } \beta \text {-d- } \\ & \text { glucoside. }\end{array}$

\section{Conflicts of Interest}

The authors declare that they have no conflicts of interest.

\section{Acknowledgments}

This study was supported by grants from the Specialized Research Fund for the National Natural Science Foundation of China (81274130 and 81973511).

\section{References}

[1] J. Neves, P. Sousa-Victor, and H. Jasper, "Rejuvenating strategies for stem cell-based therapies in aging," Cell Stem Cell, vol. 20, no. 2, pp. 161-175, 2017.

[2] M.-j. Wang, J. Chen, F. Chen et al., "Rejuvenating strategies of tissue-specific stem cells for healthy aging," Aging and Disease, vol. 10, no. 4, p. 871, 2019.

[3] A. Y. Efimenko, T. N. Kochegura, Z. A. Akopyan, and Y. V. Parfyonova, "Autologous stem cell therapy: how aging and chronic diseases affect stem and progenitor cells," BioResearch Open Access, vol. 4, no. 1, pp. 26-38, 2015.

[4] J. Wu, Z. Pan, M. Cheng et al., "Ginsenoside Rg1 facilitates neural differentiation of mouse embryonic stem cells via GRdependent signaling pathway," Neurochemistry International, vol. 62, no. 1, pp. 92-102, 2013.

[5] F.-T. Xu, H.-M. Li, Q.-S. Yin et al., "Effect of ginsenoside Rg1 on proliferation and neural phenotype differentiation of human adipose-derived stem cells in vitro," Canadian Journal of Physiology and Pharmacology, vol. 92, no. 6, pp. 467-475, 2014.

[6] Y. Si, J. Zhu, X. Huang, P. Zhu, and C. Xie, "Effects of panax notoginseng saponins on proliferation and differentiation of rat embryonic cortical neural stem cells," Journal of the Chinese Medical Association, vol. 79, no. 5, pp. 256-263, 2016.

[7] Y.-C. Si, J.-P. Zhang, C.-E. Xie, L.-J. Zhang, and X.-N. Jiang, "Effects of panax notoginseng saponins on proliferation and differentiation of rat hippocampal neural stem cells," The American Journal of Chinese Medicine, vol. 39, no. 05, pp. 999-1013, 2011.

[8] G. Guo, B. Li, Y. Wang et al., "Effects of salvianolic acid B on proliferation, neurite outgrowth and differentiation of neural stem cells derived from the cerebral cortex of embryonic mice," Science China Life Sciences, vol. 53, no. 6, pp. 653-662, 2010.

[9] Y. Zhao, P. Xu, S. Hu et al., "Tanshinone II A, a multiple target neuroprotectant, promotes caveolae-dependent neuronal differentiation," European Journal of Pharmacology, vol. 765, pp. 437-446, 2015.

[10] X. M. Zhang, J. Ma, Y. Sun et al., “Tanshinone IIA promotes the differentiation of bone marrow mesenchymal stem cells into neuronal-like cells in a spinal cord injury model," Journal of Translational Medicine, vol. 16, no. 1, p. 193, 2018.

[11] A. Morita, K. Soga, H. Nakayama, T. Ishida, S. Kawanishi, and E. F. Sato, "Neuronal differentiation of human iPS cells induced by baicalin via regulation of bHLH gene expression," Biochemical and Biophysical Research Communications, vol. 465, no. 3, pp. 458-463, 2015.

[12] M. Li, S.-T. Choi, K.-S. Tsang, P.-C. Shaw, and K.-F. Lau, "DNA microarray expression analysis of baicalin-induced differentiation of C17.2 neural stem cells," ChemBioChem, vol. 13, no. 9, pp. 1286-1290, 2012.

[13] Y. Li, P. Zhuang, B. Shen, Y. Zhang, and J. Shen, "Baicalin promotes neuronal differentiation of neural stem/progenitor cells through modulating p-stat 3 and bHLH family protein expression," Brain Research, vol. 1429, pp. 36-42, 2012.

[14] H. Gao, L. Dou, L. Shan, Y. Sun, and W. Li, "Proliferation and committed differentiation into dopamine neurons of neural stem cells induced by the active ingredients of radix astragali," NeuroReport, vol. 29, no. 7, pp. 577-582, 2018.

[15] M. Y. Li, C. T. Chang, Y. T. Han et al., "Ginkgolide B promotes neuronal differentiation through the Wnt $\beta$-catenin pathway in neural stem cells of the postnatal mammalian subventricular zone," Scientific Reports, vol. 8, no. 1, Article ID 14947, 2018.

[16] Y. M. Kim, U.-C. Sim, Y. Shin, and Y. K. Kwon, "Aucubin promotes neurite outgrowth in neural stem cells and axonal regeneration in sciatic nerves," Experimental Neurobiology, vol. 23, no. 3, pp. 238-245, 2014.

[17] M. Song, M. Han, and Y. Kim Kwon, "Effect of aucubin on neural precursor cell survival during neuronal differentiation," International Journal of Neuroscience, vol. 128, no. 10, pp. 899-905, 2018.

[18] M. Zhang, H. Zhao, Z. Li et al., "Effect of salidroside on rat bone marrow mesenchymal stem cells differentiation into cholinergic nerve cells," Zhongguo Xiu Fu Chong Jian Wai Ke Za Zhi, vol. 26, no. 2, pp. 158-165, 2012, in Chinese.

[19] S. Ling, R.-Z. Ni, Y. Yuan et al., "Natural compound bavachalcone promotes the differentiation of endothelial progenitor cells and neovascularization through the ROR $\alpha$ erythropoietin-AMPK axis," Oncotarget, vol. 8, no. 49, pp. 86188-86205, 2017.

[20] Y. Tang, B. Huang, L. Sun et al., "Ginkgolide B promotes proliferation and functional activities of bone marrow-derived endothelial progenitor cells: involvement of Akt/eNOS and MAPK/p38 signaling pathways," European Cells and Materials, vol. 28, no. 21, pp. 459-469, 2011.

[21] Y. Tang, A. Jacobi, C. Vater, L. Zou, X. Zou, and M. Stiehler, "Icariin promotes angiogenic differentiation and prevents oxidative stress-induced autophagy in endothelial progenitor cells," Stem Cells, vol. 33, no. 6, pp. 1863-1877, 2015.

[22] Z. Li, S. Zhang, L. Cao et al., "Tanshinone IIA and Astragaloside IV promote the angiogenesis of mesenchymal stem cell-derived endothelial cell-like cells via upregulation of Cx37, Cx40 and Cx43," Experimental and Therapeutic Medicine, vol. 15, no. 2, pp. 1847-1854, 2018. 
[23] W. He, W.-K. Wu, Y.-L. Wu, X.-H. Yang, Q.-X. Lin, and W.-H. Yu, "Ginsenoside-Rg1 mediates microenvironmentdependent endothelial differentiation of human mesenchymal stem cellsin vitro," Journal of Asian Natural Products Research, vol. 13, no. 1, pp. 1-11, 2011.

[24] Y. Tang, C. Vater, A. Jacobi, C. Liebers, X. Zou, and M. Stiehler, "Salidroside exerts angiogenic and cytoprotective effects on human bone marrow-derived endothelial progenitor cells via Akt/mTOR/p70S6K and MAPK signalling pathways," British Journal of Pharmacology, vol. 171, no. 9, pp. 2440-2456, 2014.

[25] Y.-J. Li, C.-L. Duan, and J.-X. Liu, "Salvianolic acid A promotes the acceleration of neovascularization in the ischemic rat myocardium and the functions of endothelial progenitor cells," Journal of Ethnopharmacology, vol. 151, no. 1, pp. 218-227, 2014.

[26] C. Wang, C. Mao, Y. Lou et al., "Monotropein promotes angiogenesis and inhibits oxidative stress-induced autophagy in endothelial progenitor cells to accelerate wound healing," Journal of Cellular and Molecular Medicine, vol. 22, no. 3, pp. 1583-1600, 2018.

[27] Y. Chen, H. Xu, Q. Wu et al., "Effects of astragalus polysaccharide in vitro intervention on proliferation, differentiation and periodic distribution of rat bone marrow derived endothelial progenitor cells," Zhong Hua Zhong Yi Yao Xue Kan, vol. 36, no. 9, pp. 2181-2184, 2018, in Chinese.

[28] Y. L. Feng, H. T. He, H. W. Miao et al., "Effects of morinda officinalis oligosaccharide on the proliferation, differentiation and paracrine of vascular endothelial progenitor cells," Zhongguo Zuzhi Gongcheng Yanjiu, vol. 22, no. 5, pp. 736741, 2018, in Chinese.

[29] D.-y. Zhu and Y.-j. Lou, "Inducible effects of icariin, icaritin, and desmethylicaritin on directional differentiation of embryonic stem cells into cardiomyocytes in vitro1," Acta Pharmacologica Sinica, vol. 26, no. 4, pp. 477-485, 2005.

[30] L. Ding, X.-G. Liang, D.-Y. Zhu, and Y.-J. Lou, "Icariin promotes expression of PGC-1?, PPAR?, and NRF-1 during cardiomyocyte differentiation of murine embryonic stem cells in vitro," Acta Pharmacologica Sinica, vol. 28, no. 10, pp. 1541-1549, 2007.

[31] L. Ding, X.-G. Liang, Y. Hu, D.-Y. Zhu, and Y.-J. Lou, "Involvement of p38MAPK and reactive oxygen species in icariin-induced cardiomyocyte differentiation of murine embryonic stem cells in vitro," Stem Cells and Development, vol. 17, no. 4, pp. 751-760, 2008.

[32] Y. Y. Kim, J. B. Ku, H. C. Liu, S.-Y. Ku, S. H. Kim, and Y. M. Choi, "Ginsenosides may enhance the functionality of human embryonic stem cell-derived cardiomyocytes in vitro," Reproductive Sciences, vol. 21, no. 10, pp. 1312-1318, 2014.

[33] S. S.-K. Chan, J.-H. Chen, S.-M. Hwang et al., "Salvianolic acid B-vitamin C synergy in cardiac differentiation from embryonic stem cells," Biochemical and Biophysical Research Communications, vol. 387, no. 4, pp. 723-728, 2009.

[34] Y. Lv, B. Liu, Y. Liu, H. Wang, and H. Wang, "TGF- $\beta 1$ combined with Sal-B promotes cardiomyocyte differentiation of rat mesenchymal stem cells," Experimental and Therapeutic Medicine, vol. 15, no. 6, pp. 5359-5364, 2018.

[35] K. Li, J. Song, Q. Zhao et al., "Effective component of salvia miltiorrhiza in promoting cardiomyogenic differentiation of human placenta-derived mesenchymal stem cells," International Journal of Molecular Medicine, vol. 41, no. 2, pp. 962-968, 2018.
[36] M. Tang, M. Yin, M. Tang et al., "Baicalin maintains latestage functional cardiomyocytes in embryoid bodies derived from murine embryonic stem cells," Cellular Physiology and Biochemistry, vol. 32, no. 1, pp. 86-99, 2013.

[37] Y. Cheng, L. Wang, M. Tang et al., "Effects of puerarin on cardiac differentiation and ventricular specialization of murine embryonic stem cells," Cellular Physiology and Biochemistry, vol. 32, no. 4, pp. 789-800, 2013.

[38] F. Song, F. Hua, H. Li et al., "Cardiac stem cell transplantation with 2,3,5,4'-tetrahydroxystilbehe-2-O- $\beta$-d-glucoside improves cardiac function in rat myocardial infarction model," Life Sciences, vol. 158, pp. 37-45, 2016.

[39] Y. Wu, L. Xia, Y. Zhou, Y. Xu, and X. Jiang, "Icariin induces osteogenic differentiation of bone mesenchymal stem cells in a MAPK-dependent manner," Cell Proliferation, vol. 48, no. 3, pp. 375-384, 2015.

[40] Q. Wei, M. He, M. Chen et al., "Icariin stimulates osteogenic differentiation of rat bone marrow stromal stem cells by increasing TAZ expression," Biomedicine \& Pharmacotherapy, vol. 91, pp. 581-589, 2017.

[41] J. M. Huang, Y. Bao, W. Xiang et al., "Icariin regulates the bidirectional differentiation of bone marrow mesenchymal stem cells through canonical Wnt signaling pathway," Evidence-Based Complementary and Alternative Medicine, vol. 2017, Article ID 8085325, 2017.

[42] X. Li, B. Peng, Y. Pan et al., "Icariin stimulates osteogenic differentiation and suppresses adipogenic differentiation of rBMSCs via estrogen receptor signaling," Molecular Medicine Reports, vol. 18, no. 3, pp. 3483-3489, 2018.

[43] M. R. Byun, H. Jeong, S. J. Bae, A. R. Kim, E. S. Hwang, and J.-H. Hong, "TAZ is required for the osteogenic and antiadipogenic activities of kaempferol," Bone, vol. 50, no. 1, pp. 364-372, 2012.

[44] J. Zhao, J. Wu, B. Xu et al., "Kaempferol promotes bone formation in part via the mTOR signaling pathway," Molecular Medicine Reports, vol. 20, no. 6, pp. 5197-5207, 2019.

[45] F. Yang, Z. W. Lin, T. Y. Huang et al., "Ligustilide, a major bioactive component of angelica sinensis, promotes bone formation via the GPR30/EGFR pathway," Scientific Reports, vol. 9, no. 1, p. 6991, 2019.

[46] D. Xu, L. Xu, C. Zhou et al., "Salvianolic acid B promotes osteogenesis of human mesenchymal stem cells through activating ERK signaling pathway," The International Journal of Biochemistry \& Cell Biology, vol. 51, pp. 1-9, 2014.

[47] X. J. Chen, Y. S. Shen, M. C. He et al., "Polydatin promotes the osteogenic differentiation of human bone mesenchymal stem cells by activating the BMP2-Wnt/ $\beta$-catenin signaling pathway," Biomedicine \& Pharmacotherapy, vol. 112, Article ID 108746, 2019.

[48] K. Qian, H. Xu, T. Dai, and K. Shi, "Effects of Tanshinone IIA on osteogenic differentiation of mouse bone marrow mesenchymal stem cells," Naunyn-Schmiedeberg's Archives of Pharmacology, vol. 388, no. 11, pp. 1201-1209, 2015.

[49] J.-J. Chen, N.-F. Zhang, G.-X. Mao et al., "Salidroside stimulates osteoblast differentiation through BMP signaling pathway," Food and Chemical Toxicology, vol. 62, pp. 499$505,2013$.

[50] Z. M. Zhang and S. F. Luo, "The role of Wnt5b in the promotion of osteogenic differentiation by puerarin," Shanghai Kou Qiang Yi Xue, vol. 25, no. 2, pp. 187-190, 2016, in Chinese.

[51] B. Zhu, F. Xue, C. Zhang, and G. Li, "Ginkgolide B promotes osteoblast differentiation via activation of canonical Wnt signalling and alleviates osteoporosis through a bone 
anabolic way," Journal of Cellular and Molecular Medicine, vol. 23, no. 8, pp. 5782-5793, 2019.

[52] Y. Zheng, J. Li, J. Wu et al., "Tetrahydroxystilbene glucoside isolated from polygonum multiflorum Thunb. demonstrates osteoblast differentiation promoting activity," Experimental and Therapeutic Medicine, vol. 14, no. 4, pp. 2845-2852, 2017.

[53] Y. Zhu, Y. Wang, Y. Jia et al., "Catalpol promotes the osteogenic differentiation of bone marrow mesenchymal stem cells via the Wnt/ $\beta$-catenin pathway," Stem Cell Research \& Therapy, vol. 10, no. 1, p. 37, 2019.

[54] A. J. Y. Guo, R. C. Y. Choi, A. W. H. Cheung et al., "Baicalin, a flavone, induces the differentiation of cultured osteoblasts," Journal of Biological Chemistry, vol. 286, no. 32, pp. 2788227893, 2011.

[55] Q. Wei, J. Zhang, G. Hong et al., "Icariin promotes osteogenic differentiation of rat bone marrow stromal cells by activating the $\mathrm{ER} \alpha$-Wnt/ $\beta$-catenin signaling pathway," Biomedicine \& Pharmacotherapy, vol. 84, pp. 931-939, 2016.

[56] C. Guo, R. Liu, H. B. Zhao, and G. H. Qin, "Wnt/ $\beta$-catenin signal pathway mediated Salidroside induced directional differentiation from mouse mesenchymal stem cells to nerve cells," Zhongguo Zhong Xi Yi Jie He Za Zhi, vol. 35, no. 3, pp. 349-354, 2015, in Chinese.

[57] J. Chen, B. Tschudy-Seney, X. Ma, M. A. Zern, P. Liu, and Y. Duan, "Salvianolic acid B enhances hepatic differentiation of human embryonic stem cells through upregulation of WNT pathway and inhibition of notch pathway," Stem Cells and Development, vol. 27, no. 4, pp. 252-261, 2018.

[58] P. Gao, J. Yang, X. Gao et al., "Salvianolic acid B improves bone marrow-derived mesenchymal stem cell differentiation into alveolar epithelial cells type I via Wnt signaling," Molecular Medicine Reports, vol. 12, no. 2, pp. 1971-1976, 2015.

[59] K. J. Lavine, A. Kovacs, and D. M. Ornitz, "Hedgehog signaling is critical for maintenance of the adult coronary vasculature in mice," The Journal of Clinical Investigation, vol. 118, no. 7, pp. 2404-2414, 2008.

[60] K. Ueda, H. Takano, Y. Niitsuma et al., "Sonic hedgehog is a critical mediator of erythropoietin-induced cardiac protection in mice," Journal of Clinical Investigation, vol. 120, no. 6, pp. 2016-2029, 2010.

[61] N. D. Lawson, A. M. Vogel, and B. M. Weinstein, "Sonic hedgehog and vascular endothelial growth factor act upstream of the notch pathway during arterial endothelial differentiation," Developmental Cell, vol. 3, no. 1, pp. 127-136, 2002.

[62] S. Kanda, Y. Mochizuki, T. Suematsu, Y. Miyata, K. Nomata, and H. Kanetake, "Sonic hedgehog induces capillary morphogenesis by endothelial cells through phosphoinositide 3kinase," Journal of Biological Chemistry, vol. 278, no. 10, pp. 8244-8249, 2003.

[63] C. Bueno-Betí, S. Novella, R. Soleti et al., "Microparticles harbouring Sonic hedgehog morphogen improve the vasculogenesis capacity of endothelial progenitor cells derived from myocardial infarction patients," Cardiovascular Research, vol. 115, no. 2, pp. 409-418, 2019.

[64] V. Ribes and J. Briscoe, "Establishing and interpreting graded sonic hedgehog signaling during vertebrate neural tube patterning: the role of negative feedback," Cold Spring Harbor Perspectives in Biology, vol. 1, no. 2, Article ID a002014, 2009.

[65] P. J. Yao, R. S. Petralia, and M. P. Mattson, "Sonic hedgehog signaling and hippocampal neuroplasticity," Trends in Neurosciences, vol. 39, no. 12, pp. 840-850, 2016.
[66] G. W. Calloni, C. Glavieux-Pardanaud, N. M. Le Douarin, and E. Dupin, "Sonic Hedgehog promotes the development of multipotent neural crest progenitors endowed with both mesenchymal and neural potentials," Proceedings of the National Academy of Sciences, vol. 104, no. 50, pp. 1987919884, 2007.

[67] T. Nakamura, T. Aikawa, M. Iwamoto-Enomoto et al., "Induction of osteogenic differentiation by hedgehog proteins," Biochemical and Biophysical Research Communications, vol. 237, no. 2, pp. 465-469, 1997.

[68] S. Spinella-Jaegle, G. Rawadi, S. Kawai et al., "Sonic hedgehog increases the commitment of pluripotent mesenchymal cells into the osteoblastic lineage and abolishes adipocytic differentiation," Journal of Cell Science, vol. 114, no. 11, pp. 2085-2094, 2001

[69] F. Huang, Y. Lan, L. Qin et al., "Astragaloside IV promotes adult neurogenesis in hippocampal dentate gyrus of mouse through CXCL1/CXCR2 signaling," Molecules, vol. 23, no. 9, 2178 pages, 2018.

[70] J. Xie, H. Wang, T. Song et al., "Tanshinone IIA and astragaloside IV promote the migration of mesenchymal stem cells by up-regulation of CXCR4," Protoplasma, vol. 250, no. 2, pp. 521-530, 2013.

[71] C. Wang, Y. Li, X. Yang et al., "Tetramethylpyrazine and astragaloside IV synergistically ameliorate left ventricular remodeling and preserve cardiac function in a rat myocardial infarction model," Journal of Cardiovascular Pharmacology, vol. 69, no. 1, pp. 34-40, 2017.

[72] L. H. Guo, Y. Cao, R. T. Zhuang, Y. Han, and J. Li, "Astragaloside IV promotes the proliferation and migration of osteoblast-like cells through the hedgehog signaling pathway," International Journal of Molecular Medicine, vol. 43 , no. 2, pp. 830-838, 2019.

[73] Z. Hui, D. J. Sha, S. L. Wang et al., "Panaxatriol saponins promotes angiogenesis and enhances cerebral perfusion after ischemic stroke in rats," BMC Complementary and Alternative Medicine, vol. 17, no. 1, p. 70, 2017.

[74] Y. Zhang, X. Zhang, L. Cui et al., "Salvianolic acids for injection (safi) promotes functional recovery and neurogenesis via sonic hedgehog pathway after stroke in mice," Neurochemistry International, vol. 110, pp. 38-48, 2017.

[75] P. Yu, L. Wang, F. Tang et al., "Resveratrol pretreatment decreases ischemic injury and improves neurological function via sonic hedgehog signaling after stroke in rats," Molecular Neurobiology, vol. 54, no. 1, pp. 212-226, 2017.

[76] Q.-H. Meng, H.-B. Liu, and J.-B. Wang, "Polydatin ameliorates renal ischemia/reperfusion injury by decreasing apoptosis and oxidative stress through activating sonic hedgehog signaling pathway," Food and Chemical Toxicology, vol. 96, pp. 215-225, 2016.

[77] Y. Li, M. Han, P. Lin et al., "Hair growth promotion activity and its mechanism of polygonum multiflorum," EvidenceBased Complementary and Alternative Medicine, vol. 2015, Article ID 517901, 2015.

[78] J.-Y. Tian, W.-W. Chen, J. Cui et al., "Effect of lycium bararum polysaccharides on methylmercury-induced abnormal differentiation of hippocampal stem cells," Experimental and Therapeutic Medicine, vol. 12, no. 2, pp. 683-689, 2016.

[79] W. Zhao, X. Pan, T. Li, C. Zhang, and N. Shi, "Lycium barbarum polysaccharides protect against trimethyltin chloride-induced apoptosis via sonic hedgehog and PI3K/ Akt signaling pathways in mouse neuro-2a cells," Oxidative Medicine and Cellular Longevity, vol. 2016, pp. 1-18, 2016. 
[80] X. Li, G. Wei, X. Wang et al., "Targeting of the Sonic Hedgehog pathway by atractylenolides promotes chondrogenic differentiation of mesenchymal stem cells," Biological and Pharmaceutical Bulletin, vol. 35, no. 8, pp. 1328-1335, 2012.

[81] Z. Yang, L. Wang, and X. Wang, "Matrine induces the hepatic differentiation of WB-F344 rat hepatic progenitor cells and inhibits jagged 1/HES1 signaling," Molecular Medicine Reports, vol. 14, no. 4, pp. 3841-3847, 2016.

[82] H.-B. Zhao, S.-N. Qi, J.-Z. Dong et al., "Salidroside induces neuronal differentiation of mouse mesenchymal stem cells through notch and BMP signaling pathways," Food and Chemical Toxicology, vol. 71, pp. 60-67, 2014.

[83] H. Hu, R. Yang, G. Jin et al., "Effect of astragaloside IV on neural stem cell transplantation in alzheimer's disease rat models," Evidence-Based Complementary and Alternative Medicine, vol. 2016, Article ID 3106980, 8 pages, 2016.

[84] Y. Yan, L. Kong, Y. Xia et al., "Osthole promotes endogenous neural stem cell proliferation and improved neurological function through notch signaling pathway in mice acute mechanical brain injury," Brain, Behavior, and Immunity, vol. 67, pp. 118-129, 2018.

[85] H. Zhu, X. Wang, Y. Han et al., "Icariin promotes the migration of bone marrow stromal cells via the SDF- $1 \alpha / \mathrm{HIF}-1 \alpha /$ CXCR 4 pathway," Drug Design, Development and Therapy, vol. 12, pp. 4023-4031, 2018.

[86] H. Liu, Y. Xiong, X. Zhu et al., "Icariin improves osteoporosis, inhibits the expression of $\mathrm{PPAR} \gamma, \mathrm{C} / \mathrm{EBP} \alpha, \mathrm{FABP} 4$ mRNA, N1ICD and jagged1 proteins, and increases notch2 mRNA in ovariectomized rats," Experimental and Therapeutic Medicine, vol. 13, no. 4, pp. 1360-1368, 2017.

[87] Y. Matsumoto, J. La Rose, O. A. Kent et al., "Reciprocal stabilization of ABL and TAZ regulates osteoblastogenesis through transcription factor RUNX2," Journal of Clinical Investigation, vol. 126, no. 12, pp. 4482-4496, 2016.

[88] D. El Ouarrat, R. Isaac, Y. S. Lee et al., "TAZ is a negative regulator of PPAR $\gamma$ activity in adipocytes and TAZ deletion improves insulin sensitivity and glucose tolerance," Cell Metabolism, vol. 31, no. 1, pp. 162-173.e5, 2020.

[89] Y. Ye, X. Jing, N. Li, Y. Wu, B. Li, and T. Xu, "Icariin promotes proliferation and osteogenic differentiation of rat adipose-derived stem cells by activating the RhoA-TAZ signaling pathway," Biomedicine \& Pharmacotherapy, vol. 88, pp. 384-394, 2017.

[90] D. Xin, H. Wang, J. Yang et al., "Phytoestrogens from Psoralea corylifolia reveal estrogen receptor-subtype selectivity," Phytomedicine, vol. 17, no. 2, pp. 126-131, 2010.

[91] A. L. Strong, R. B. Jones, J. Glowacki, S. M. Boue, M. E. Burow, and B. A. Bunnell, "Glycinol enhances osteogenic differentiation and attenuates the effects of age on mesenchymal stem cells," Regenerative Medicine, vol. 12, no. 5, pp. 513-524, 2017.

[92] T. Wang, D. Wan, L. Shao, J. Dai, and C. Jiang, "Notoginsenoside R1 stimulates osteogenic function in primary osteoblasts via estrogen receptor signaling," Biochemical and Biophysical Research Communications, vol. 466, no. 2, pp. 232-239, 2015.

[93] W. Tiyasatkulkovit, N. Charoenphandhu, K. Wongdee, J. Thongbunchoo, N. Krishnamra, and S. Malaivijitnond, "Upregulation of osteoblastic differentiation marker mRNA expression in osteoblast-like UMR106 cells by puerarin and phytoestrogens from Pueraria mirifica," Phytomedicine, vol. 19, no. 13, pp. 1147-1155, 2012.

[94] Y.-K. Zhai, X.-Y. Guo, B.-F. Ge et al., "Icariin stimulates the osteogenic differentiation of rat bone marrow stromal cells via activating the PI3K-AKT-eNOS-NO-cGMP-PKG," Bone, vol. 66, pp. 189-198, 2014.

[95] D.-Y. Zhu and Y.-J. Lou, "Icariin-mediated expression of cardiac genes and modulation of nitric oxide signaling pathway during differentiation of mouse embryonic stem cells into cardiomyocytes in vitro1," Acta Pharmacologica Sinica, vol. 27, no. 3, pp. 311-320, 2006.

[96] K. Mujoo, L. E. Nikonoff, V. G. Sharin, N. S. Bryan, A. Y. Kots, and F. Murad, "Curcumin induces differentiation of embryonic stem cells through possible modulation of nitric oxide-cyclic GMP pathway," Protein \& Cell, vol. 3, no. 7, pp. 535-544, 2012.

[97] X. Zhang, L. Zou, J. Li et al., "Salvianolic acid B and danshensu induce osteogenic differentiation of rat bone marrow stromal stem cells by upregulating the nitric oxide pathway," Experimental and Therapeutic Medicine, vol. 14, no. 4, pp. 2779-2788, 2017.

[98] X. Yao, X. Jing, J. Guo et al., "Icariin protects bone marrow mesenchymal stem cells against iron overload induced dysfunction through mitochondrial fusion and fission, PI3K/ AKT/mTOR and MAPK pathways," Frontiers in Pharmacology, vol. 10, p. 163, 2019.

[99] Y. N. Chen, H. Liu, H. B. Zhao et al., "Salidroside via ERK1/2 and PI3K/AKT/mTOR signal pathway induces mouse bone marrow mesenchymal stem cells differentiation into neural cells," Yao Xue Bao, vol. 48, no. 8, pp. 1247-1252, 2013, in Chinese.

[100] X. Liu, Y. Niu, W. Xie, D. Wei, and Q. Du, “Tanshinone IIA promotes osteogenic differentiation of human periodontal ligament stem cells via ERK1/2-dependent Runx2 induction," American Journal of Translational Research, vol. 11, no. 1, pp. 340-350, 2019.

[101] M. Aouadi, F. Bost, L. Caron, K. Laurent, Y. Le Marchand Brustel, and B. Binétruy, "p38 mitogen-activated protein kinase activity commits embryonic stem cells to either neurogenesis or cardiomyogenesis," Stem Cells, vol. 24, no. 5, pp. 1399-1406, 2006.

[102] L. Ding, X. G. Liang, D. Y. Zhu, and Y. J. Lou, "Icariin promotes expression of PGC-1alpha, PPARalpha, and NRF1 during cardiomyocyte differentiation of murine embryonic stem cells in vitro," Acta Pharmacologica Sinica, vol. 28, no. 10, pp. 1541-1549, 2007.

[103] D. Y. Kim, K. H. Park, M. S. Jung et al., "Ginsenoside Rh2 (S) induces differentiation and mineralization of MC3T3-E1 cells through activation of the PKD/AMPK signaling pathways," International Journal of Molecular Medicine, vol. 28, no. 5, pp. 753-759, 2011.

[104] I. I. Suvorova, A. R. Knyazeva, A. V. Petukhov et al., "Resveratrol enhances pluripotency of mouse embryonic stem cells by activating AMPK/Ulk1 pathway," Cell Death Discovery, vol. 5, no. 1, p. 61, 2019.

[105] C.-Y. Lin, Y.-T. Chin, P.-J. Kuo et al., "2,3,5,4'-Tetrahydroxystilbene-2-O- $\beta$-glucoside potentiates self-renewal of human dental pulp stem cells via the AMPK/ERK/SIRT1 axis," International Endodontic Journal, vol. 51, no. 10, pp. 1159-1170, 2018.

[106] K. M. Imran, D. Yoon, and Y.-S. Kim, "A pivotal role of AMPK signaling in medicarpin-mediated formation of brown and beige," BioFactors, vol. 44, no. 2, pp. 168-179, 2018.

[107] K. M. Imran, N. Rahman, D. Yoon, M. Jeon, B.-T. Lee, and Y.-S. Kim, "Cryptotanshinone promotes commitment to the brown adipocyte lineage and mitochondrial biogenesis in C3H10T1/2 mesenchymal stem cells via AMPK and p38- 
MAPK signaling," Biochimica et Biophysica Acta (BBA) Molecular and Cell Biology of Lipids, vol. 1862, no. 10, pp. 1110-1120, 2017.

[108] H. Liu, M. M. Fergusson, R. M. Castilho et al., "Augmented Wnt signaling in a mammalian model of accelerated aging," Science, vol. 317, no. 5839, pp. 803-806, 2007.

[109] J. C. Yoon, A. Ng, B. H. Kim, A. Bianco, R. J. Xavier, and S. J. Elledge, "Wnt signaling regulates mitochondrial physiology and insulin sensitivity," Genes \& Development, vol. 24, no. 14, pp. 1507-1518, 2010.

[110] D. Y. Zhang, Y. Pan, C. Zhang et al., "Wnt/ $\beta$-catenin signaling induces the aging of mesenchymal stem cells through promoting the ROS production," Molecular and Cellular Biochemistry, vol. 374, no. 1-2, pp. 13-20, 2013.

[111] L. García-Velázquez and C. Arias, "The emerging role of Wnt signaling dysregulation in the understanding and modification of age-associated diseases," Ageing Research Reviews, vol. 37, pp. 135-145, 2017.

[112] Y. Xiang, S. H. Wang, L. Wang et al., "Effects of ginsenoside Rg1 regulating wnt $/ \beta$-catenin signaling on neural stem cells to delay brain senescence," Stem Cells International, vol. 2019, Article ID 5010184, 12 pages, 2019.

[113] J. Li, D. Cai, X. Yao et al., "Protective effect of ginsenoside Rg1 on hematopoietic stem/progenitor cells through attenuating oxidative stress and the wnt $/ \beta$-catenin signaling pathway in a mouse model of d-Galactose-induced aging," International Journal of Molecular Sciences, vol. 17, no. 6, p. 849, 2016.

[114] A. Cho, S.-R. Park, S.-R. Kim et al., "An endogenous antiaging factor, sonic hedgehog, suppresses endometrial stem cell aging through SERPINB2," Molecular Therapy, vol. 27, no. 7, pp. 1286-1298, 2019.

[115] B. Hai, Q. Zhao, M. A. Deveau, and F. Liu, "Delivery of sonic hedgehog gene repressed irradiation-induced cellular senescence in salivary glands by promoting DNA repair and reducing oxidative stress," Theranostics, vol. 8, no. 4, pp. 1159-1167, 2018.

[116] K. Matsumoto, T. Shimo, N. Kurio et al., "Expression and role of sonic hedgehog in the process of fracture healing with aging," Vivo, vol. 30, no. 2, pp. 99-105, 2016.

[117] H. Takebe, N. Shalehin, A. Hosoya et al., "Sonic hedgehog regulates bone fracture healing," International Journal of Molecular Sciences, vol. 21, no. 2, p. 677, 2020.

[118] J. Mikuła-Pietrasik, A. Kuczmarska, B. Rubiś et al., "Resveratrol delays replicative senescence of human mesothelial cells via mobilization of antioxidative and DNA repair mechanisms," Free Radical Biology and Medicine, vol. 52, no. 11-12, pp. 2234-2245, 2012.

[119] L. Xia, X. X. Wang, X. S. Hu et al., "Resveratrol reduces endothelial progenitor cells senescence through augmentation of telomerase activity by Akt-dependent mechanisms," British Journal of Pharmacology, vol. 155, no. 3, pp. 387-394, 2008.

[120] J. Wang, C. Huang, Z. Lin et al., "Polydatin suppresses nucleus pulposus cell senescence, promotes matrix homeostasis and attenuates intervertebral disc degeneration in rats," Journal of Cellular and Molecular Medicine, vol. 22, no. 11, pp. 5720-5731, 2018.

[121] X. Han, S. Ling, W. Gan, L. Sun, J. Duan, and J.-W. Xu, " $2,3,5,4$ '-tetrahydroxystilbene-2-O- $\beta$-d-glucoside ameliorates vascular senescence and improves blood flow involving a mechanism of p53 deacetylation," Atherosclerosis, vol. 225, no. 1, pp. 76-82, 2012.
[122] S. Ling, J. Duan, R. Ni, and J. W. Xu, “2,3,5,4'-tetrahydroxystilbene-2-o- $\beta$-d-glucoside promotes expression of the longevity gene klotho," Oxidative Medicine and Cellular Longevity, vol. 2016, Article ID 3128235, 11 pages, 2016.

[123] Z.-J. Liu, Y. Tan, G. W. Beecham et al., "Notch activation induces endothelial cell senescence and pro-inflammatory response: implication of notch signaling in atherosclerosis," Atherosclerosis, vol. 225, no. 2, pp. 296-303, 2012.

[124] D. Venkatesh, N. Fredette, B. Rostama et al., "RhoA-mediated signaling in Notch-induced senescence-like growth arrest and endothelial barrier dysfunction," Arteriosclerosis, Thrombosis, and Vascular Biology, vol. 31, no. 4, pp. 876-882, 2011.

[125] Y. V. Teo, N. Rattanavirotkul, N. Olova et al., "Notch signaling mediates secondary senescence," Cell Reports, vol. 27, no. 4, pp. 997-1007.e5, 2019.

[126] M. Hoare, Y. Ito, T.-W. Kang et al., "NOTCH1 mediates a switch between two distinct secretomes during senescence," Nature Cell Biology, vol. 18, no. 9, pp. 979-992, 2016.

[127] G. X. Mao, Y. Wang, Q. Qiu et al., "Salidroside protects human fibroblast cells from premature senescence induced by $\mathrm{H}_{2} \mathrm{O}_{2}$ partly through modulating oxidative status," Mechanisms of Ageing and Development, vol. 131, no. 11-12, pp. 723-731, 2010.

[128] S.-S. Xing, J. Li, L. Chen et al., "Salidroside attenuates endothelial cellular senescence via decreasing the expression of inflammatory cytokines and increasing the expression of SIRT3," Mechanisms of Ageing and Development, vol. 175, pp. 1-6, 2018.

[129] M. Song, H. Kim, S. Park, H. Kwon, I. Joung, and Y. K. Kwon, "Aucubin promotes differentiation of neural precursor cells into GABAergic neurons," Experimental Neurobiology, vol. 27, no. 2, pp. 112-119, 2018.

[130] H.-Y. Kim, S.-Y. Park, and S.-Y. Choung, "Enhancing effects of myricetin on the osteogenic differentiation of human periodontal ligament stem cells via BMP-2/Smad and ERK/ JNK/p38 mitogen-activated protein kinase signaling pathway," European Journal of Pharmacology, vol. 834, pp. 84-91, 2018.

[131] X. Ying, X. Chen, Y. Feng et al., "Myricetin enhances osteogenic differentiation through the activation of canonical $\mathrm{Wnt} / \beta$-catenin signaling in human bone marrow stromal cells," European Journal of Pharmacology, vol. 738, pp. 2230, 2014.

[132] K. Tao, D. Xiao, J. Weng, A. Xiong, B. Kang, and H. Zeng, "Berberine promotes bone marrow-derived mesenchymal stem cells osteogenic differentiation via canonical Wnt/ $\beta$-catenin signaling pathway," Toxicology Letters, vol. 240, no. 1, pp. 68-80, 2016.

[133] X. Ying, L. Sun, X. Chen et al., "Silibinin promotes osteoblast differentiation of human bone marrow stromal cells via bone morphogenetic protein signaling," European Journal of Pharmacology, vol. 721, no. 1-3, pp. 225-230, 2013.

[134] Y. J. Kim, Y. C. Bae, K. T. Suh, and J. S. Jung, "Quercetin, a flavonoid, inhibits proliferation and increases osteogenic differentiation in human adipose stromal cells," Biochemical Pharmacology, vol. 72, no. 10, pp. 1268-1278, 2006.

[135] C. Zhou and Y. Lin, "Osteogenic differentiation of adiposederived stem cells promoted by quercetin," Cell Proliferation, vol. 47, no. 2, pp. 124-132, 2014.

[136] Y. Li, J. Wang, G. Chen et al., "Quercetin promotes the osteogenic differentiation of rat mesenchymal stem cells via mitogen-activated protein kinase signaling," Experimental and Therapeutic Medicine, vol. 9, no. 6, pp. 2072-2080, 2015. 
[137] Y. Zhou, Y. Wu, X. Jiang et al., "The effect of quercetin on the osteogenesic differentiation and angiogenic factor expression of bone marrow-derived mesenchymal stem cells," PLoS One, vol. 10, no. 6, Article ID e0129605, 2015.

[138] J.-G. Huang, C.-B. Shen, W.-B. Wu et al., "Primary cilia mediate sonic hedgehog signaling to regulate neuronal-like differentiation of bone mesenchymal stem cells for resveratrol induction in vitro," Journal of Neuroscience Research, vol. 92, no. 5, pp. 587-596, 2014.

[139] I.-S. Joe, S.-G. Jeong, and G.-W. Cho, "Resveratrol-induced SIRT1 activation promotes neuronal differentiation of human bone marrow mesenchymal stem cells," Neuroscience Letters, vol. 584, pp. 97-102, 2015.

[140] S. Jahan, S. Singh, A. Srivastava et al., "PKA-GSK3 $\beta$ and $\beta$-catenin signaling play a critical role in trans-resveratrol mediated neuronal differentiation in human cord blood stem cells," Molecular Neurobiology, vol. 55, no. 4, pp. 2828-2839, 2018.

[141] M. Shakibaei, P. Shayan, F. Busch et al., "Resveratrol mediated modulation of Sirt-1/Runx2 promotes osteogenic differentiation of mesenchymal stem cells: potential role of Runx2 deacetylation," PLoS One, vol. 7, no. 4, Article ID e35712, 2012.

[142] C. P. Erdman, C. R. Dosier, R. Olivares-Navarrete et al., "Effects of resveratrol on enrichment of adipose-derived stem cells and their differentiation to osteoblasts in two-and three-dimensional cultures," Journal of Tissue Engineering and Regenerative Medicine, vol. 6, no. S3, pp. s34-s46, 2012.

[143] N. Zhang, T. Kang, Y. Xia et al., "Effects of salvianolic acid B on survival, self-renewal and neuronal differentiation of bone marrow derived neural stem cells," European Journal of Pharmacology, vol. 697, no. 1-3, pp. 32-39, 2012.

[144] T. Shu, C. Liu, M. Pang et al., "Salvianolic acid B promotes neural differentiation of induced pluripotent stem cells via PI3K/AKT/GSK3 $\beta / \beta$-catenin pathway," Neuroscience Letters, vol. 671, pp. 154-160, 2018. 